University of Michigan Law School

University of Michigan Law School Scholarship Repository

\title{
Federal Forum Provisions and the Internal Affairs Doctrine
}

\author{
Dhruv Aggarwal \\ Yale Law School and Yale School of Management \\ Albert H. Choi \\ University of Michigan Law School, alchoi@umich.edu \\ Ofer Eldar \\ Duke Law School and Duke Fuqua School of Business
}

Available at: https://repository.law.umich.edu/articles/2169

Follow this and additional works at: https://repository.law.umich.edu/articles

Part of the Business Organizations Law Commons, Legislation Commons, Litigation Commons, and the Securities Law Commons

\section{Recommended Citation}

Choi, Albert H. "Federal Forum Provisions and the Internal Affairs Doctrine." Dhruv Aggarwal and Ofer Eldar, co-authors. Harv. Bus. L. Rev. 10, no. 2 (2020): 383-434.

This Article is brought to you for free and open access by the Faculty Scholarship at University of Michigan Law School Scholarship Repository. It has been accepted for inclusion in Articles by an authorized administrator of University of Michigan Law School Scholarship Repository. For more information, please contact mlaw.repository@umich.edu. 


\title{
FEDERAL FORUM PROVISIONS AND THE INTERNAL AFFAIRS DOCTRINE
}

\author{
Dhruv Aggarwal, * Albert H. Chol,** \\ $\&$ OFER ELDAR $* * *$
}

\begin{abstract}
A key question at the intersection of state and federal law is whether corporations can use their charters or bylaws to restrict securities litigation to federal court. In December 2018, the Delaware Chancery Court answered this question in the negative in the landmark decision Sciabacucchi v. Salzberg. The court invalidated "federal forum provisions" ("FFPs") that allow companies to select federal district courts as the exclusive venue for claims brought under the Securities Act of 1933 ("1933 Act"). The decision held that the internal affairs doctrine, which is the bedrock of U.S. corporate law, does not permit charter and bylaw provisions that restrict rights under federal law. In March 2020, the Delaware Supreme Court overturned the Chancery's decision in Salzberg v. Sciabacucchi, holding that in addition to "internal" affairs, charters and bylaws can regulate "intra-corporate" affairs, including choosing the forum for Securities Act claims.

This Article presents the first empirical analysis of federal forum provisions. Using a hand-collected data set, we examine the patterns of adoption of such provisions and the characteristics of adopting firms. We show that adoption rates are higher for firms with characteristics, such as belonging to a particular industry, that make them more vulnerable to claims under the 1933 Act. We also show that adoption rates substantially increased after the Supreme Court decision in Cyan Inc. v. Beaver County Employees Retirement Fund, which validated concurrent jurisdiction for both federal and state courts for 1933 Act claims. We also find that the firms that adopt FFPs at the initial public offering ("IPO") stage tend to share characteristics that have been associated with relatively good corporate governance. To assess the impact of the Sciabacucchi decision, we also conduct an event study. We find that the decision is associated with a large negative stock price effect for companies that had FFPs in their charters or bylaws. The effect is robust even for firms that had better governance features, that underpriced their stock at the IPOs, and whose stock price traded at or above the IPO price prior to the Sciabacucchi decision.

In light of the empirical findings suggesting that federal forum provisions may serve shareholders' interests by mitigating excessive 1933 Act litigation, we consider alternative legal theories for validating federal forum provisions in corporate charters and bylaws. We suggest two possible approaches: (1) allowing corporate charters and bylaws to address matters that are technically external but deal with the "affairs" of the corporation; and (2) adopting a more "flexible" internal affairs doctrine that could view 1933 Act claims as being "internal” to a corporation's affairs. The Delaware Supreme Court's decision
\end{abstract}

* JD/PhD Candidate, Yale Law School and Yale School of Management.

** Professor of Law, University of Michigan Law School.

*** Associate Professor of Law and Finance, Duke Law School and Duke Fuqua School of Business.

For helpful comments and suggestions, we thank Emiliano Catan, Stephen Choi, Jens Dammann (discussant), Elisabeth de Fontenay, Joe Grundfest, Scott Hirst, Daniel Klerman, Ann Lipton, Adam Pritchard, Gabriel Rauterberg, Roberta Romano, Michael Simkovic, Steven Davidoff Solomon (discussant), Emily Strauss, and participants in seminars at Georgetown Law School, Notre Dame Law School, USC Law School, the conference on Rethinking the Shareholder Franchise at Wisconsin Law School, and the annual Conference on Empirical Legal Studies. We also thank Shaoqin Tang for excellent research assistance. 
can be viewed as being more consistent with the first, rather than the second, approach. We examine the possible implications of adopting either approach, particularly with respect to mandatory arbitration provisions and the existing Delaware statute on exclusive forum provisions.

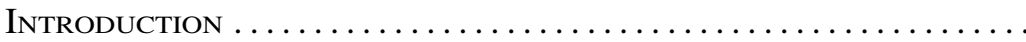

I. The History of Forum Selection in Securities Class Action Lawsuits ...............................

II. What is at Stake? The Differences between Lawsuits in Federal Courts and State Courts ............. 394

III. Which Firms Adopt Federal Exclusive Provisions? .... 398 IV. Measuring the Effect of Sciabacucchi on Firm Value 403

A. Data and Empirical Strategy ................... 403

B. Results............................... 406

V. Implications of the EMpiRical Results ............ 408

VI. Sciabacucchi and the Delaware Supreme Court's

REVERSAL .................................. 410

A. The Boundaries of the Corporate Contract .......... 412

B. The Boundaries of Internal Affairs ............... 416

Conclusion........................................ 421

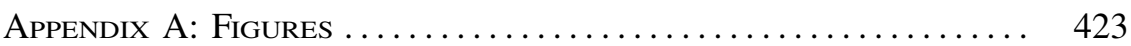

ApPendix B: Tables ................................ 425

Appendix C: Variable Descriptions .................... 433

\section{INTRODUCTION}

Should a company be allowed to dictate the forum in which its shareholders can bring suit? This has been one of the most vexing and controversial issues in corporate and securities law in recent years. Proponents argue that a large fraction of shareholder lawsuits against corporations (or their directors and officers) lack merit, or are even frivolous, and the lawyers representing shareholders (especially in class actions) often engage in forum shopping simply to maximize their chances of success. ${ }^{1}$ Allowing the corporation to dictate the forum, possibly even using a mandatory arbitration provision, would help curb the abusive shareholder lawsuits and bring sanity back to the system. ${ }^{2}$ Opponents, on the other hand, argue that depriving shareholders of the right to bring suit-especially class action suits-in the forum they choose can substantially curtail, or even deny, a fundamental

${ }^{1}$ See, e.g., Minor Myers, Fixing Multi-Forum Shareholder Litigation, 2014 U. ILL. L. Rev. 467 (2014); Roberta Romano, The Shareholder Suit: Litigation Without Foundation?, 7 J.L. ECON. \& ORG. 55 (1991).

${ }^{2}$ See Hal Scott, Shareholder Deserve Right to Choose Mandatory Arbitration, CLS BLuE SKY BLOG (Aug. 21, 2017), http://clsbluesky.law.columbia.edu/2017/08/21/shareholders-deserve-right-to-choose-mandatory-arbitration/ (discussing SEC Commissioner Piwowar's remark that the US public companies "can come to [the SEC] to ask for relief to put . . mandatory arbitration into their charters"). 
right given to shareholders and can worsen the agency problem between managers and shareholders. ${ }^{3}$

At least with respect to lawsuits based on corporate law and for corporations incorporated in Delaware, the issue seems fairly well settled. In the 2013 case Boilermakers Local 154 Retirement Fund v. Chevron Corp., the Delaware Chancery Court ruled that, as long as a corporation's charter allows the directors to unilaterally amend its bylaws, the directors can exercise that right to unilaterally include an exclusive forum clause. ${ }^{4}$ In 2015, the Delaware legislature amended the Delaware General Corporate Law ("DGCL") to expressly allow corporations to have a forum selection clause in their charters or bylaws. ${ }^{5}$ A key element of the decision and the statutory amendment is that forum selection for claims under states' corporate law is governed by the internal affairs doctrine. That doctrine states that only one state - the state of incorporation-has authority to regulate a corporation's internal affairs, and according to Boilermakers, those internal affairs include the forum for litigating claims under the state's corporate law.

Forum selection with respect to federal securities lawsuits, on the other hand, is more controversial. An important debate has taken place over whether corporations can dictate in their charters and bylaws the forum for lawsuits based on federal securities laws. One plausible argument is that the internal affairs doctrine regulates only claims that arise under state law and does not extend to rights under federal law. On the other hand, it is difficult to ascertain a clear substantive distinction between shareholder lawsuits under state corporate law and similar lawsuits under federal law. Both federal and state lawsuits often raise similar issues (such as disclosure and voting rights issues) and relate to the rights and powers of shareholders. ${ }^{6} \mathrm{~A}$

\footnotetext{
${ }^{3}$ See Ann Lipton, Locked Out: The Carlyle Group Tries to Bar Investors from Court, Advocate For Inst. Inv. Summer 2012, at 4, 6-7 (citing, for instance, how arbitration tends to favor corporations over individual investors).

${ }^{4}$ Boilermakers Loc. 154 Retirement Fund v. Chevron Corp., 73 A.3d 934, 963 (Del. Ch. 2013). In upholding such a bylaw, the court applied the "contractarian" approach. According to the court, "the bylaws constitute a binding part of the contract between a Delaware corporation and its stockholders," and when the right to amend the bylaws has been granted to the directors, the shareholders "will be bound by bylaws adopted unilaterally by their boards." Id. at 955-56. Almost all public corporations incorporated in Delaware have a charter provision that grants bylaw modification rights to their directors. See Albert H. Choi \& Geeyoung Min, Contractarian Theory and Unilateral Bylaw Amendments, 104 Iowa L. Rev. 1 (2018).

${ }^{5}$ See 8 Del. Code AnN., $\S 109,115$ (2018).

${ }^{6}$ We do not discuss the broader question of whether the charter and bylaws should be permitted to regulate matters that go beyond the internal or intra-corporate affairs, as this requires a more detailed reexamination of Boilermakers which is beyond the scope of this Article. Naturally, if shareholders and the company entered into a shareholders' agreement that specifies a forum for federal securities lawsuits, there would be little doubt that courts would enforce it. See Bonanno v. VTB Holdings, Inc., No. 10681-VCN, 2016 WL 614412, at *15 (Del. Ch. 2016); Germaninvestments AG v. Allomet Corp., No. 2018-0666-JRS, 2019 WL 2236844, at*10 (Del. Ch. 2019), rev'd on other grounds ("Stockholders can expressly waive Delaware venue in a contract between stockholders and the corporation"). Recently, the Delaware Supreme Court had the opportunity to consider the argument that such contractual arrangements (using shareholders' agreements) would frustrate the purpose of DGCL $\$ 115$, since
} 
more flexible internal affairs doctrine would deal with the matters that are "internal" to the corporation, without making a formalistic distinction based on whether a claim is based on federal or state law.

Although forum selection for federal securities lawsuits remained unsettled, since 2017, a growing number of firms have pushed the envelope by adopting exclusive federal forum provisions ("FFPs") that seek to constrain shareholders by only allowing federal law claims under the Securities Act of 1933 ("1933 Act") to be brought in federal court.7 The 1933 Act, which governs claims for material misstatements or omissions in initial public offerings ("IPOs"), specifically commits jurisdiction over these claims to both state and federal courts. FFPs were adopted in high-profile initial public offerings, such as that of Snap, Inc., with the specific goal of restricting lawsuits for material misstatements or omissions in the IPO documents to federal courts. Furthermore, as the Article shows, the rate of adoptions of these FFPs significantly accelerated following the 2018 Supreme Court decision Cyan v. Beaver County Employees Retirement Fund, ${ }^{8}$ which expressly validated the plaintiffs' right to bring 1933 Act lawsuits in state courts.

But what about the validity of FFPs in charters and bylaws? The answer was given several months later. In Sciabacucchi v. Salzberg, ${ }^{9}$ decided on December 19, 2018, the Delaware Chancery Court held that a company's charter and bylaws cannot dictate the forum in which the shareholders may bring a federal claim. ${ }^{10}$ The court reasoned that a corporation's organizational documents can only address internal corporate affairs, and that claims under federal law exceed the legal bounds of the corporation's organizational documents. ${ }^{11}$ Thus, under the Chancery Court's reasoning, the internal affairs doctrine does not encompass state law provisions that regulate rights under federal law. Thus, while Cyan made the adoption of FFPs more attractive, Sciabacucchi took away that option. On March 18, 2020, however, the Delaware Supreme Court overturned the Chancery Court's decision in Salzberg v. Sciabacucchi. ${ }^{12}$ The Supreme Court focused heavily on the statutory language of DGCL §102(b) and made a distinction between internal versus in-

"Delaware corporations could simply eliminate Delaware as a choice of forum with mandatory forum selection clauses" outside charters and bylaws. However, since the Supreme Court decided that case on other grounds, it declined to resolve this important question. See Germaninvestments AG v. Allomet Corp., No. 291, 2020 WL 414426, at*21 (Del. 2020). At any rate, such agreements are likely impractical in the context of public issuance of shares to dispersed shareholders.

${ }^{7}$ See infra fig. 1 (showing how increasing numbers of IPO companies have adopted federal forum provisions since 2017).

${ }^{8}$ Cyan, Inc. v. Beaver County Emp. Retirement Fund, 138 S. Ct. 1061 (2018).

${ }^{9}$ Sciabacucchi v. Salzberg, No. 2017-0931-JTL, 2018 Del. Ch. LEXIS 578, at*3 (2018).

${ }^{10}$ According to the court, a claim based on a federal securities law is an "external" claim (a claim that resides outside of the boundaries of corporate law), and a corporate document, such as a certificate of incorporation or bylaws, cannot regulate such a claim. $I d$. at $* 41$.

${ }^{11}$ See id. at *3 ("The constitutive documents of a Delaware corporation cannot bind a plaintiff to a particular forum when the claim does not involve rights or relationships that were established by or under Delaware's corporate law.").

${ }^{12}$ See Salzberg v. Sciabacucchi, 2020 Del. LEXIS 100 (Del. 2020). 
tra-corporate affairs. Based on the statutory language, the Court ruled that charters and bylaws can regulate intra-corporate affairs, including claims based on the federal Securities Act.

In the midst of this back-and-forth, some important policy questions remained unanswered. Should companies be allowed to have an FFP in either their charter or bylaws? How important is an FFP for a company? Why would some companies utilize them while others do not? So far there has been no systematic investigation of how widespread or how important FFPs are, and this Article attempts to fill that gap. Through an empirical analysis, it takes a closer look at the use of FFPs in companies' organizational documents and evaluates the impact of the Chancery Court's decision (Sciabacucchi case) on shareholder value. The Article makes several important findings.

First, using hand-collected data, we document the adoption of FFPs since 2017 and analyze the characteristics of firms that adopted such provisions. FFPs were adopted mainly after the Cyan decision by firms that are undergoing IPOs and that are more likely to be the target of lawsuits under the 1933 Act. More specifically, they more likely belong to industries, such as computer software and pharmaceuticals, that have traditionally been more vulnerable to federal securities lawsuits. In addition, they tend to raise larger proceeds in their IPOs, yet exhibit negative earnings, which suggests that their valuations are based on uncertain future growth. Nonetheless, we do not find that these firms exhibit characteristics that arguably reflect greater agency problems, such as dual-class structures. ${ }^{13}$ To the contrary, these IPOs tend to be backed by venture capital and private equity firms, which are typically associated with better governance structures at the IPO stage (such as more independent boards)..$^{14}$ Moreover, these firms tend to underprice their IPOs, meaning that their stock prices exhibit a larger increase on the first day of trading. This evidence suggests that these firms are seeking to reduce the risk of litigation, and that the investors in these IPOs are less likely to suffer a loss.

Second, to answer the question of whether the FFPs matter and, if so, how much, we conduct an event study of the Sciabacucchi decision to evaluate its impact on the value of the firms with FFPs. We find that the decision

${ }^{13}$ Dual-class stock companies, such as Google and Facebook, are companies with two or more classes of shares with different voting rights. Typically, one class of shares has more than 50 percent of the voting rights, but substantially lower cash flow rights. This creates the risk that the controller will manage the firm to benefit itself at the expense of other shareholders. For discussion of dual-class structures, see, e.g., Ronald W. Masulis et al., Agency Problems at Dual-Class Companies, 64 J. Fin. 1697 (2009); Lucian A. Bebchuk \& Kobi Kastiel, The Perils of Small-Minority Controllers, 107 Geo. L.J. 1453 (2019); Albert H. Choi, Concentrated Ownership and Long-Term Shareholder Value, 8 HARv. Bus. L. REV. 53 (2018); Zohar Goshen \& Assaf Hamdani, Corporate Control and Idiosyncratic Vision,125 YALE. L. J. 560 (2016).

${ }^{14}$ This is consistent with a study that shows that companies that adopted exclusive forum clauses in their bylaws had better corporate governance features than nonadopters. See Roberta Romano \& Sarath Sanga, The Private Ordering Solution to Multiforum Shareholder Litigation, 14 J. Empirical Legal Stud. 31, 66-71 (2017). 
is associated with a large negative stock price effect. ${ }^{15}$ Moreover, this effect exists even if we limit the analysis to firms that belong to industries that are vulnerable to federal securities lawsuits; to firms that adopted the provision in their charters (as opposed to the bylaws), thereby making it harder for shareholders to amend the provision; and to firms that are less vulnerable to agency costs by excluding firms that have a dual-class stock structure.

To be sure, the negative shock around the Sciabacucchi decision does not necessarily mean that FFPs are beneficial to shareholders. First, as is applicable to all event studies, there may be intervening events around the decision that may have contributed to the result. Second, the decline in stock prices may reflect the higher likelihood that firms will have to pay larger amounts in future settlements (or judgments) rather than the desirability of these provisions. Nonetheless, there are reasons to believe that our results do reflect, at least to some extent, investors' overall view of the decision. As we explain below, the recovery amounts in these lawsuits are unlikely to exceed the negative effect associated with the decision. Moreover, this negative effect is robust even if we evaluate only firms that are less likely to pay large amounts in settlements, firms that underpriced their stocks at the IPO, and firms whose stocks traded at above the IPO price just before the Sciabacucchi decision.

Taken together, our findings are consistent with a growing line of research that points to the excessive costs and distorted incentives that underlie forum shopping by plaintiffs. ${ }^{16}$ Foremost, the findings support reforming the 1933 Act to require the filing of claims only in federal courts, consistent with its twin act, the Securities Exchange Act of 1934, which governs fraud in the secondary market. They also suggest that there are good reasons to reconsider the merits of the Sciabacucchi decision and validate FFPs in corporate charters and bylaws. While we agree that the legal basis underlying Sciabacucchi is sensible, we offer a few alternative approaches to reading the Delaware statute and interpreting the case law. The first alternative approach would allow charters and bylaws to deal with matters, such as 1933 Act claims, that may be viewed as being technically "external" but still

${ }^{15}$ This is consistent with a recent study that finds that forum selection clauses increase firm value by reducing the probability of multijurisdictional litigation. See Jared I. Wilson, The Consequences of Limiting Shareholder Litigation: Evidence from Exclusive Forum Provisions (July 10, 2019) (unpublished manuscript) (https://papers.ssrn.com/sol3/papers.cfm?abstract_id $=2646312$ ). While our hope is to be able to conduct some additional empirical studies (including an event study) based on the Delaware Supreme Court's decision, because the decision came down in the middle of the coronavirus pandemic and extremely high stock market volatility, we are skeptical that any meaningful event study can be conducted based on the Supreme Court's decision.

${ }^{16}$ See, e.g., Ofer Eldar \& Neel U. Sukhatme, Will Delaware Be Different? An Empirical Study of TC Heartland and the Shift to Defendant Choice of Venue, 104 CORNell L. Rev. 101 (2018); Daniel Klerman \& Greg Reilly, Forum Selling, 89 S. CAL. L. Rev. 241 (2016); Elisabeth Kempf \& Oliver Spalt, Litigating Innovation: Evidence from Securities Class Action Lawsuits (European Corp. Gov. Inst., Working Paper No. 614/2019, 2019), https://papers.ssrn .com/sol3/papers.cfm?abstract_id=3143690. 
dealing with the "affairs" or "intra-corporate affairs" of the corporation and the "rights" of the stockholders. This is the approach largely adopted by the Delaware Supreme Court in Salzberg.

While making the distinction between intra-corporate versus internal affairs may be sensible, that is not the only way to allow charters and bylaws to choose the forum for federal Securities Act claims. The second approach would argue for a more "flexible" internal affairs doctrine so as to encompass matters that intimately relate to the rights of the shareholders, including the right to bring a 1933 Act claim. We discuss the legal basis for each alternative and potential implications of adopting one over the other. We also argue that validating FFPs does not necessarily, at least as a matter of policy, imply the validation of more controversial provisions, particularly mandatory (individual) arbitration provisions that can potentially deny shareholders the right to sue under the 1933 Act altogether. After all, even when FFPs are enforced, shareholders are still free to bring their 1933 Act claims in federal court, either individually or as a class action. At the same time, as we explain below, expanding the sphere of internal affairs (the second approach) means that blocking mandatory arbitration and fee-shifting clauses would be statutorily mandated, whereas under the first approach, that door remains open.

This Article proceeds as follows. Part I discusses in more detail the history of forum selection in securities class action lawsuits. Part II explains the importance of FFPs by describing the differences in litigating cases in federal courts versus state courts. Part III begins the empirical analysis by examining the characteristics of firms that adopt FFPs. Part IV conducts an event study of the Sciabacucchi decision. Part V discusses the implications of the empirical findings for assessing FFPs and the Sciabacucchi decision. Part VI reconsiders the legal basis of Sciabacucchi and offers a few alternative legal theories for validating FFPs, including the approach taken by the Delaware Supreme Court in Salzberg.

\section{The History of Forum Selection in Securities Class Action Lawsuits}

Congress passed two prominent statutes after the Great Depression: the Securities Act of $1933^{17}$ ("1933 Act") and the Securities and Exchange Act of $1934^{18}$ ("1934 Act"). While there is much complexity and overlap, the 1933 Act largely deals with the types of information a company must disclose to its prospective investors when issuing new securities, such as at an initial public offering ("IPO"), at a secondary offering, or in the context of a merger. Thus, it governs claims primarily alleging misstatements and omissions in disclosure materials relating to offerings of securities. Specifically,

${ }^{17} 15$ U.S.C. $\$ 77$ (2018).

${ }^{18} 15$ U.S.C. $\$ 78$ (2018). 
Section 11 of the 1933 Act governs material omissions and misstatements in a company's registration statement, ${ }^{19}$ and Section 12 imposes liability for selling unregistered securities, failing to follow the SEC's "gun jumping" rules, and making material misstatements or omissions in prospectuses. ${ }^{20}$ The 1934 Act, on the other hand, deals with fraud in transactions on the secondary market, including misstatements in "periodic" and other disclosures, proxy statements for shareholder meetings, and liability for insider trading (under Rule 10b-5). ${ }^{21}$

With respect to shareholder lawsuits that are based on the 1934 Act, the federal courts have exclusive jurisdiction..$^{22}$ If certain plaintiff-shareholders are alleging a material misstatement or omission in a corporation's proxy statement or insider trading, for instance, they must bring the case, individually or as a class, in federal court. ${ }^{23}$ Shareholder lawsuits brought under the 1933 Act, on the other hand, are a different matter. Unlike the 1934 Act, federal and state courts have had concurrent jurisdiction over 1933 Act claims from the time of its enactment. ${ }^{24}$ If plaintiff-shareholders want to bring a material misstatement or an omission claim based on a company's IPO documents (such as its S-1 registration statement or prospectus), they can do so in either federal or state court.

Much has changed, however, since the enactment of the 1933 Act. Leading up to the 1990s, Congress became increasingly concerned with the impact of securities class actions, particularly the abundance of frivolous lawsuits brought by plaintiffs' lawyers in the hope of extracting settlements for meritless but expensive claims. ${ }^{25}$ In response, Congress enacted the Private Securities Litigation Reform Act ("PSLRA"), ${ }^{26}$ which imposed many restrictions on securities class actions brought in federal courts. Key among these were a stay imposed on discovery prior to decisions on motions to dismiss, restrictions on lead plaintiffs, and potentially higher pleading standards. We further discuss the import of these restrictions in Part II.

${ }^{19}$ See 15 U.S.C. $\S 77 \mathrm{k}$ (2018). A Section 11 plaintiff recovers the "excess" price she paid for a share because of a material misstatement or omission in the issuer's registration statement. See 15 U.S.C. § 77k(e) (2018).

${ }^{20}$ See 15 U.S.C. $§ 771$ (2018). See generally Steven Thel, Section 12(2) of the Securities Act: Does Old Legislation Matter?, 63 Fordham L. Rev. 1183 (1995).

${ }^{21}$ See Blue Chip Stamps v. Manor Drug Stores, 421 U.S. 723, 752 (1975).

2215 U.S.C. § 78aa (2018); see also Cyan, Inc. v. Beaver County Emp. Ret. Fund, 138 S. Ct. 1061, 1073 (2018).

${ }^{23}$ See, e.g., Shearson/Am. Express, Inc. v. McMahon, 482 U.S. 220, 245 n.2 (Blackmun, J., concurring).

${ }^{24}$ See 15 U.S.C. $\$ 77 \mathrm{v}(\mathrm{a})(2018)$.

${ }^{25}$ See James D. Cox et al., Securities Regulation: Cases and Materials 785-86 (8th ed. 2017); see also Joel Seligman, The Merits Do Matter: A Comment on Professor Grundfests' "Disimplying Private Rights of Action Under the Federal Securities Laws: The Commission's Authority”, Harv. L. Rev. 438 (1994); Private Securities Litigation, Staff Report, Senate Subcommittee on Securities of the Comm. On Banking, Housing and Urban Affairs, 98th Cong., 2d Sess. 108 (May 17, 1994).

${ }^{26}$ Pub. L. No. 104-67, 109 Stat. 737 (1995) (codified as amended in scattered sections of 15 U.S.C.). 
Faced with these restraints, plaintiffs' lawyers sought creative ways to circumvent them. One primary means was by bringing securities class actions under "blue sky" state law in state courts (as a substitute to claims under the 1934 Act), ${ }^{27}$ where the strictures of the PSLRA did not apparently apply. ${ }^{28}$ Observing the flight of securities class actions to state courts, Congress passed the Securities Litigation Uniform Standards Act ("SLUSA") in $1998 .{ }^{29}$ SLUSA provided for the removal of state securities law class actions to federal court, and then for their dismissal. . $^{30}$

However, although the purpose of SLUSA was to bring securities class actions back within the ambit of the federal courts (and thus within the restrictions of the PSLRA), ${ }^{31}$ SLUSA did not address class actions brought solely under the 1933 Act. Could such class actions still be brought in state court, even though this would permit the end-run around the PSLRA that SLUSA was designed to prevent? For nearly twenty years, courts across the country split on the issue. The Ninth Circuit permitted 1933 Act claims to be remanded to state courts, notwithstanding SLUSA. ${ }^{32}$ Other district courts, ${ }^{33}$ particularly those of the Second Circuit, the "mother circuit" for securities litigation, ${ }^{34}$ held that 1933 Act claims in state court were precluded by SLUSA.

Largely in response to this jurisdictional uncertainty and the alleged abuse by plaintiff-shareholders (and plaintiffs' lawyers) in bringing federal IPO-related claims in state courts, ${ }^{35}$ a number of companies began experimenting with exclusive forum provisions in their IPO documents. ${ }^{36}$ The first series of attempts centered on including mandatory arbitration clauses in charters. This effort was led by the Carlyle Group, a private equity company,

27 "Blue sky" laws are specialized state statutes that govern securities sales. See generally Jonathan R. Macey \& Geoffrey P. Miller, Origin of the Blue Sky Laws, 70 Tex. L. Rev. 347 (1991).

${ }^{28}$ See Klausner et al., infra note 45, at 3-6. The differences between securities litigation in federal and state courts are discussed in Part II.

${ }^{29}$ Securities Litigation Uniform Standards Act of 1998, Pub. L. No. 105-353, 112 Stat. 3227 (1998) (codified as amended in scattered sections of 15 U.S.C.).

${ }^{30} 15$ U.S.C. $\$ 78 \mathrm{bb}(\mathrm{f})(2018)$.

${ }^{31}$ See, e.g., Kircher v. Putnam Funds Trust, 547 U.S. 633, 636 (2006); Merrill Lynch, Pierce, Fenner \& Smith, Inc. v. Dabit, 547 U.S. 71, 82 (2006).

${ }^{32}$ See, e.g., Elec. Workers Local 357 Pension and Health \& Welfare Tr. v. Clovis Oncology, Inc., 185 F. Supp. 3d 1172 (N.D. Cal. 2016); W. Va. Laborers Trust Fund v. STEC Inc., No. 11-01171-JVS (MLGx), 2011 WL 6156945 (C.D. Cal. Oct. 7, 2011).

${ }^{33}$ See, e.g., Iron Workers Dist. Council of New England Pension Fund v. MoneyGram Int'l, Inc., No. 15-402-LPS, 2016 WL 4585975 (D. Del. Sept. 2, 2016); Gaynor v. Miller, et al., No. 3:15-cv-545-TAV-CCS, 2016 WL 6078340 (E.D. Tenn. Sept. 8, 2016).

${ }^{34}$ See, e.g., Hung v. iDreamsky Tech. Ltd., No. 15-CV-2514 (JPO), 2016 WL 299034, at *2 (S.D.N.Y. Jan. 25, 2016).

${ }^{35}$ See Nicki Locker \& Laurie Smilan, Saying So Long to State Court Securities Litigation, Harv. L. Sch. F. on Corp. Governance \& Fin. Reg. (2019) ("Securities class action plaintiffs have achieved a much higher rate of success in surviving threshold motions in IPO-related federal securities class actions litigated in state courts, extracting significant settlements out of proportion to results typically achieved in federal fora.").

${ }^{36}$ See infra Part III (providing an empirical account of IPO firms' experimentation with federal forum provisions). 
when it was offering its limited partnership shares to the public. Due in part to the public backlash against the proposal and the Securities and Exchange Commission's ("SEC") unwillingness to accommodate, however, the Carlyle Group dropped the proposal. ${ }^{37}$ However, the debate on mandatory arbitration provisions lives on. ${ }^{38}$

A more successful attempt - the main focus of this Article-was the adoption of federal forum provisions ("FFPs") in a company's charter or bylaws. Most notably, the first FFP in the organizational documents of an IPO firm was by Snap, Inc. in February 2017. Snap's charter designated federal district courts in any state as the exclusive forum for claims brought under the 1933 Act. ${ }^{39}$ Unlike the mandatory individual arbitration clause, which prohibited shareholders from even filing a class action suit, a typical FFP merely prohibits plaintiff-shareholders from bringing an IPO-related 1933 Act claim in state court. That is, plaintiff-shareholders are free to bring a class or an individual action, so long as the action is filed in federal court.

An important implication of requiring plaintiff-shareholders to file in a federal court, of course, is that they will be subject to various requirements of the PSLRA..$^{40}$ A large number of companies with FFPs went through the IPO process, or issued securities after a merger, without any major challenge or backlash from the investors or the SEC. ${ }^{41}$ However, the legality of FFPs, and the question of whether a court would uphold them, remained unsettled until very recently.

In 2018, the Supreme Court resolved the jurisdictional uncertainty regarding 1933 Act claims. In Cyan v. Beaver County Employees Retirement Fund ${ }^{42}$ the Supreme Court construed SLUSA narrowly, stating that while SLUSA prevented private plaintiffs from bringing claims under the 1934

${ }^{37}$ Kevin Roose, Carlyle Drops Arbitration Clause from IPO Plans, N.Y. TIMEs, Feb. 3, 2012, https://dealbook.nytimes.com/2012/02/03/carlyle-drops-arbitration-clause-from-i-p-oplans/. Professor Davidoff described Carlyle Group's proposal as "the most shareholder-unfriendly corporate governance structure in modern history . . . The effect is to essentially eliminate any ability of shareholders to sue the board for even the most egregious acts." See Lipton, supra note 3 , at 7 . In response to the proposal, three U.S. Senators sent a letter to the SEC chairman, requesting that the commission deny the proposal. See Letter from Franken, Blumenthal, and Menendez, U.S. Senators, to Mary Schapiro, Chair, Sec. \& Exch. Comm'n, (Feb. 3, 2012).

${ }^{38}$ See Scott, supra note 2.

${ }^{39}$ See Snap Inc., Registration Statement (Form S-1) 43 (Feb. 2, 2017); Ann Lipton, And Now for Something Completely Different about Snap and Shareholder Rights, Bus. LAw ProfBLOG. (Apr. 15, 2017), https://lawprofessors.typepad.com/business_law/2017/04/and-now-forsomething-completely-different-about-snap-and-shareholder-rights.html.

${ }^{40}$ It should be noted that as discussed in Part II, some state judges have held that PLSRA's discovery stay applies in both state and federal courts, preserving one of the act's primary protections for securities defendants. See infra note 54 and accompanying text.

${ }^{41}$ See Cydney Posner, Cooley, Will the Delaware Supreme Court Revive Exclusive Federal Forum Provisions for '33 Act Claims? (Jan. 9, 2020), https://cooleypubco.com/2020/01/ 09/will-delaware-revive-exclusive-federal-forum-provisions/ ("FFPs have been described in dozens of registration statements, but the SEC has never challenged the validity of these provisions or raised the question to the Delaware courts for determination.").

${ }^{42} 138$ S. Ct. 1061 (2018). 
Act under state law, it did not take away state courts' power to hear claims under the 1933 Act. ${ }^{43}$ Furthermore, according to the Court, SLUSA did not allow the defendants to remove a properly filed state court claim to a federal court. ${ }^{44}$ That is, once a 1933 Act lawsuit has been filed in a state court, it is extremely difficult to move that lawsuit to a federal court without the plaintiff's consent.

Cyan sparked two major developments in a very short period of time. The first was a dramatic increase in 1933 Act claims filed in state courts, for which there was often a parallel case brought in federal court against the same defendant based on the same allegations..$^{45}$ The second was the proliferation of FFPs, particularly in IPOs. As we document below, the proportion of IPOs that included FFPs more than doubled almost immediately after Cyan, and continued increasing in the following months. FFPs, therefore, were responding to plaintiffs possibly choosing their favored venue of state, rather than federal, court. The FFPs, in some sense, "flipped the table," allowing corporate defendants to preemptively dictate the venue even before a 1933 Act lawsuit was filed. ${ }^{46}$

The question remained, however, as to whether courts would respect FFPs. The answer was given several months later. In December 2018, the Delaware Chancery Court held in Sciabacucchi v. Salzberg that a company's organizational documents, i.e. its charter and the bylaws, cannot dictate the forum in which the shareholders may bring a federal claim. ${ }^{47}$ The court based its decision on its interpretation of the proper scope of the internal affairs doctrine: "the state of incorporation cannot use corporate law to regulate the corporation's external relationships." 48 According to the court, a claim based on a federal securities law is an "external" claim (a claim that resides outside of the boundaries of corporate law), and a corporate docu-

43 The central question in Cyan was whether SLUSA's provisions stripping state courts of jurisdiction over "covered class actions" extended to all lawsuits filed on behalf of fifty or more people. Justice Kagan's opinion held that SLUSA only stripped state courts of covered class actions based on state law. See id. at 1069-71. The unanimous Court held that SLUSA "says nothing, and so does nothing, to deprive state courts of jurisdiction over class actions based on federal law." Id. at 1069. Therefore, state courts continue to have concurrent jurisdiction over class actions based on the 1933 Act.

${ }^{44} \mathrm{Id}$. at 1078 .

${ }^{45}$ See Joseph A. Grundfest, The Limits of Delaware Corporate Law: Internal Affairs, Federal Forum Provisions, and Sciabacucchi, 75 Bus. LAw. 1319 (2020). Notably, the article documents a notable rise in the $\mathrm{D} \& \mathrm{O}$ insurance premium, which also covers liability based on federal securities laws. Id. at 20-23. See generally Michael Klausner et al., State Section 11 Litigation in the Post-Cyan Environment (Jun. 28, 2019) (unpublished manuscript) (https:// papers.ssrn.com/sol3/papers.cfm?abstract_id=3411861).

${ }^{46}$ Cf. Eldar \& Sukhatme, supra note 16 (exploring a similar role reversal caused by the Supreme Court's TC Heartland case, which shifted venue choice in patent infringement cases from plaintiffs to corporate defendants).

${ }^{47}$ Sciabacucchi v. Salzberg, 204 A.3d 841 (Del. Ch. Dec. 19, 2018).

${ }^{48} I d$. at $* 20$. 
ment, such as a certificate of incorporation or bylaws, cannot regulate such a claim. ${ }^{49}$

Unsurprisingly, as we show below, the decision led to a substantial slowdown in the adoption of FFPs, and some companies have even issued a special 8-K to investors in order to inform the market about the invalidity of the provision. In some cases, companies issuing an $8-\mathrm{K}$ promised to amend their charter or bylaws (as applicable) if the decision is not reversed by the Delaware Supreme Court. ${ }^{50}$ On the other hand, other IPO companies, such as Lyft, adopted an FFP in their charter despite the decision, possibly in the hope that Sciabacucchi would be reversed. ${ }^{51}$

In March 2020, perhaps fulfilling their expectations, the Delaware Supreme Court did just that in Salzberg v. Sciabacucchi..$^{52}$ The Court focused heavily on the statutory language of DGCL $\$ 102(b)$, which allows corporations to include matters relating to the "affairs of the corporation" and provisions that "create[], define[], limit[] and regulate[] the powers of the corporation, the directors, and the stockholders" in their charters. By contrasting this language with that of DGCL $\$ 115$, which prohibits non-Delaware forum provision with respect to "internal affairs," the Delaware Supreme Court held that the matters that relate to stockholders' right to sue under the federal Securities Act, while not part of a corporation's internal affairs, can be classified as "intra-corporate" affairs and, therefore, can be regulated through charters and bylaws.

\section{What is at Stake? The Differences between Lawsuits in Federal Courts and State Courts}

It is important to recall that FFPs do not prohibit filing lawsuits; they only require plaintiff-shareholders to file their claim in federal court. Thus, it may be argued that Sciabacucchi does not matter much because all it means is that IPO firms will be sued in state courts instead of federal courts. However, due to the different procedural rules, whether a firm is sued in federal court or in state court can matter a great deal for the outcome of a case. There are four main differences between lawsuits in federal and state courts.

First, in federal court, the PSLRA dictates that discovery is stayed until after the motion to dismiss is decided. ${ }^{53}$ This procedural rule spares defendants the cost of discovery in lawsuits that are dismissed, and imposes on plaintiffs the costs of obtaining detailed information without the benefits of

${ }^{49} I d$. at $* 1$.

${ }^{50}$ See, e.g., Surface Oncology, Inc., Current Report (Form 8-K) (Feb. 13, 2019) ("In the event that the Delaware Supreme Court affirms the Court of Chancery's Sciabacucchi decision or otherwise makes a determination that provisions such as the Federal Forum Provision are invalid, the Company's Board of Directors intends to amend promptly the Company's Bylaws to remove the Federal Forum Provision.").

${ }^{51}$ See Lyft, Inc., Registration Statement (Form S-1) 60 (Mar. 1, 2019).

${ }^{52}$ Salzberg v. Sciabacucchi, 2020 Del. LEXIS 100 (Del. 2020).

${ }^{53} 15$ U.S.C. $§ 77 \mathrm{z}-1$ (b) (2018). See Klausner et al., supra note 45, at 5. 
discovery. To be sure, some states have adopted discovery rules that resemble those of the PSLRA. Recently, trial courts in New York and Connecticut ruled that the PSLRA's discovery stay applies not only to 1933 Act Section 11 actions in federal court but also to Section 11 actions in in state court. ${ }^{54}$ However, states like California-where many IPO firms are headquartered, including over 50 percent of the firms that adopted FFPs-adopt more lenient standards than the PSLRA. Specifically, California allows discovery to commence before the motion to dismiss stage concludes, thereby substantially increasing the cost borne by the defendants. ${ }^{55}$

Second, the PLSRA imposes various requirements on the identity of lead plaintiff. In particular, there is a presumption that the court should appoint as lead plaintiff the class member with the largest financial interest in the relief sought. ${ }^{56}$ The lead plaintiff has the authority to select and retain class counsel, which is a coveted position for plaintiffs' lawyers. This requirement has been relatively effective in preventing unscrupulous lawyers from recruiting nominal plaintiffs and filing claims solely to advance their interests..$^{57}$ There is a possibility that Section 11 actions in state courts will be filed by opportunistic lawyers representing plaintiffs with minimal economic losses, just to extract nominal settlements from deep-pocket defendants who want the case to go away. ${ }^{58}$

Third, although federal courts have a well-developed process for consolidating securities class action lawsuits, there is no analogous process for securities claims brought in state courts. The federal consolidation process allows cases brought by dispersed shareholders in different jurisdictions against the same defendant alleging the same charges to be tried together, in one venue, under one or several lead plaintiffs. These rules facilitate judicial economy and facilitate consistent results by having similar cases tried in one court instead of many. They may also reduce costs for defendants, who need only defend the action in one venue. ${ }^{59}$ However, there is currently no method

${ }^{54}$ See In re Everquote, Inc. Sec. Litig., 106 N.Y.S.3d 828, 828 (N.Y. Sup. Ct. Aug. 7, 2019); City of Livonia Retiree Health \& Disability Benefits Plan v. Pitney Bowes Inc., No. X08 FST CV 186038160 S (Conn. Super. Ct. May 15, 2019); see also Klausner et al., supra note 45, at 13-14 nn.26-27 (collecting cases where state courts are either staying their proceedings pending resolution of a parallel federal case, or staying discovery pursuant to the PSLRA).

${ }^{55}$ See, e.g., Buelow v. Alibaba Grp. Holding Ltd., No. 15-cv-05179-BLF, 2016 WL 234159 (N.D. Cal. Jan. 20, 2016) (refusing to stay discovery pursuant to PSLRA).

${ }^{56}$ See 15 U.S.C. $\$ 77 z-1(\mathrm{a})(3)(\mathrm{B})$ (2018).

${ }^{57}$ See, e.g., Stephen J. Choi et al., Do Institutions Matter? The Impact of the Lead Plaintiff Provision of the Private Securities Litigation Reform Act, 83 WASH. U. L. REV. 869 (2005) (finding that public institutions began serving as lead plaintiff more often after the passage of PSLRA, and that this was associated with increases in class recoveries).

${ }^{58}$ For an example of a state court that authorized a lead plaintiff that had previously been found woefully inadequate when bringing the same action in federal court, see In re BankAmerica Corp. Sec. Litig., 95 F.Supp.2d 1044, 1049 (E.D. Mo. 2000), aff'd, 263 F.3d 795 (8th Cir. 2001).

59 See 15 Charles Alan Wright \& Arthur R. Miller, Federal Practice and ProceDURE $§ \S 3861-62$ (4th ed. 2019); George T. Conway III, Note, The Consolidation of Multistate 
for similarly consolidating actions brought in the courts of multiple states, or consolidating parallel state and federal actions. Although some state courts may facilitate judicial economy by applying the doctrines of lis pendens (staying the case until a federal court decides on the matter) or forum non conveniens (dismissing the case in favor of a more suitable forum, whether federal court or the courts of another state), they may choose not to do so. ${ }^{60}$ Accordingly, defendants may incur more costs defending such actions in multiple venues, and different courts may reach different conclusions based on the same facts.

Fourth, federal courts require pleadings in Section 11 cases to adhere to the Twombly/Iqbal standard: the plaintiff must allege "enough facts to state a claim to relief that is plausible on its face," ${ }^{61}$ and cannot rely on conclusory statements in making their case. ${ }^{62}$ Most federal courts hearing Section 11 claims apply the even more stringent pleading standard imposed by Rule 9(b) of the Federal Rules of Civil Procedure to the extent that such cases are based on "fraud" claims. ${ }^{63}$ Under Rule 9(b), a complaint must "state with particularity the circumstances constituting fraud or mistake." ${ }^{64}$ In contrast, the pleading standards in many states' courts are more lenient than either the Twombly/Iqbal or Rule 9(b) frameworks. ${ }^{65}$ In particular, the standard in California merely requires a plaintiff to plead a "statement of the facts constituting the cause of action, in ordinary and concise language." ${ }^{\prime 6}$

Finally, there is a concern that state judges may be unduly favorable to plaintiffs. With exceptions (most notably the Delaware Chancery Court), state judges appointed through a partisan process or through popular elections are likely to be more susceptible to political pressure, and state judges may lack the technical competence of federal court judges ${ }^{67}$ For example,

Litigation in State Courts, 96 YALE L.J. 1099 (1987) (praising the federal multidistrict litigation system for promoting judicial economy and consistency, and advocating for a similar system of consolidation at the state court level).

${ }^{60}$ See Klausner et al., supra note 45 , at 6.

${ }^{61}$ Bell Atl. Corp. v. Twombly, 550 U.S. 544, 570 (2007).

${ }^{62}$ Bell, 550 U.S. at 561; Ashcroft v. Iqbal, 556 U.S. 662, 678 (2009)

${ }^{63}$ See Marc I. Steinberg \& Brent A. Kirby, The Assault on Section 11 of the Securities Act: A Study in Judicial Activism, 63 Rutgers L. Rev. 1, 38-39 (2010) (noting that "the circuits are virtually unanimous in holding that Section 11 claims that sound in fraud are subject to the heightened pleading requirements of Rule 9(b)").

${ }^{64}$ Fed. R. CIV. P. 9(b).

${ }^{65}$ Only five states and the District of Columbia have adopted the Twombly/Iqbal pleading standards, while many state courts have applied their more lenient pleading standards to federal claims. See Zachary D. Clopton, Procedural Retrenchment and the States, 106 CALIF. L. Rev. 411, 424-27 (2018).

${ }^{66}$ Cal. Civ. Proc. Code $§ 425.10$ (West 2016). See Klausner et al., supra note 45, at 5 (noting that the standard in New York may be higher).

${ }^{67}$ See, e.g., Burt Neuborne, The Myth of Parity, 90 Harv. L. Rev. 1105, 1122 (1977) (arguing that state judges were less technically proficient and less insulated from political pressure); Adam Bonica \& Maya Sen, The Politics of Selecting the Bench from the Bar: The Legal Profession and Partisan Incentives to Introduce Ideology into Judicial Selection, 60 J.L. \& ECON. 559 (2017) (finding that judges are more partisan in systems where they are elected, rather than appointed). 
California's judicial system-in which judges are either appointed by the Governor or popularly elected ${ }^{68}$-is ranked 47 th by the United States Chamber of Commerce in its influential survey of state judicial climates for corporate defendants. ${ }^{69}$ Local judges may be more favorable to local law firms whose lawyers often share the same background as the judges, and local judges may want to encourage local litigation in order to enhance their own reputation..$^{70}$

Recent trends in forum-shopping in Section 11 cases following the Cyan decision demonstrate that these differences have an impact on where plaintiffs file cases. A recent study found a sharp increase in the proportion of cases filed in state courts in 2018 . The number of cases filed exclusively in federal courts fell from 67 percent in the period from 2014 to March 2018 to only 23 percent from March to December 2018. ${ }^{71}$ Most of the filings occur in New York, where cases were previously removed to federal court based on a narrow construction of SLUSA, and California, where many of the IPO firms are headquartered. ${ }^{72}$ There is also a decline in filings in federal courts against California-headquartered firms. ${ }^{73}$ Overall, these preliminary trends are consistent with a broader phenomenon of forum shopping by plaintiffs towards jurisdictions that would be most receptive to their litigation strategy. ${ }^{74}$

Moreover, the ongoing trend towards filing in state court is consistent with evidence that shows that the outcomes in state courts tend to be less favorable to corporate defendants. The percentage of state court cases in which a motion to dismiss is granted is substantially lower than that of federal court cases (19 percent in state courts as compared to 42 percent in

${ }^{68}$ See Judicial Selection in the States: California, Natl. Ctr. For State Cts., http:// www.judicialselection.us/judicial_selection/index.cfm?state $=$ CA.

69 See David Krane et al., 2017 Lawsuit Climate Survey: Ranking the States, U.S. Chamber of Commerce, 9 (2017), Stephen J. Choi et al., Judicial Evaluations and Information Forcing: Ranking State High Courts and Their Judges, 58 Duke L.J. 1313, 1327 (2009).

${ }^{70}$ See Jonathan R. Macey \& Geoffrey P. Miller, Toward an Interest-Group Theory of Delaware Corporate Law, 65 Tex. L. Rev. 469, 502 (1987) (arguing that Delaware's "bar and the judiciary are tied together through an intricate web of personal and professional contacts"); William L. Cary, Federalism and Corporate Law: Reflections Upon Delaware, 83 Yale L.J. 663, 687-88 (1974) (observing that state judges are often drawn from the ranks of the state bar, and can develop legal doctrine and procedural rules to benefit their former colleagues).

${ }^{71}$ See Klausner et al., supra note 45 , at 8-9.

${ }^{72}$ See id. at 7.

${ }^{73}$ See Stefan Boettrich \& Svetlana Starykh, Recent Trends in Securities Class Action Litigation: 2018 Full-Year Review, NERA Economic Consulting 10 (2019).

${ }^{74}$ See, e.g., William H.J. Hubbard, An Empirical Study of the Effect of Shady Grove v. Allstate on Forum Shopping in the New York Courts, 10 J.L. Econ. \& PoL'Y 151 (2013); Neel U. Sukhatme, A Theoretical and Empirical Study of Forum Shopping in Diversity Cases (2014) (unpublished manuscript) (https://papers.ssrn.com/sol3/papers.cfm?abstract_id=19892 50); Klerman \& Reilly, supra note 16, at 242-47; Eldar \& Sukahtme, supra note 16, at 158 n.211; Andrew D. Bradt \& D. Theodore Rave, Aggregation on Defendants' Terms: BristolMyers Squibb and the Federalization of Mass-Tort Litigation, 59 B.C. L. REV. 1251, 1254 (2018). 
federal courts from 2011 to 2018). ${ }^{75}$ Section 11 lawsuits litigated in state courts settle more often than those in federal courts, presumably because more of the latter do not survive motions to dismiss. Specifically, from 2011 to 2018 , the settlement rate was 59 percent in claims litigated solely in federal court, 65 percent in claims litigated solely in state court, and 83 percent if the claim was litigated in both state and federal court. ${ }^{76}$ While there is no clear evidence that settlement amounts in state courts are materially different from those in federal courts, ${ }^{77}$ the lower rate of dismissal and higher probability of settlement suggest that the overall litigation expenses for corporate defendants are substantially higher in state courts as compared to federal courts.

In light of the above, it is easy to see why FFPs may be important for firms that are susceptible to Section 11 lawsuits. An FFP may mean that the firm is much more likely to have claims dismissed, thereby avoiding not only the possibility of making a settlement payment, but perhaps more importantly avoiding the reputational and the opportunity costs associated with litigating cases that may not be meritorious. One study suggests that the negative stock price impact associated with securities class action litigation can be substantial. ${ }^{78}$ Accordingly, FFPs may save substantial costs for firms, particularly those that wish to go public, and likewise, the Sciabacucchi decision that prohibited FFPs likely had the opposite effect. Thus, it is not surprising that after Cyan, and prior to Sciabacucchi, several law firms predicted that more IPO firms would adopt FFPs in their organizational documents. $^{79}$

\section{Which Firms Adopt Federal Exclusive Provisions?}

In this part, we empirically examine the pattern of FFP provision adoptions. We manually collected data on exclusive forum provisions from the

75 See Klausner et al., supra note 45 , at 10.

${ }^{76}$ See id. at 11.

77 The median settlement amount in state Section 11 lawsuits was greater than that for federal cases, but the latter cases had a higher mean settlement amount. It has only been approximately a year since Cyan, so the relative settlement amounts for state and federal Section 11 lawsuits could change as parties adjust their litigating strategies with time. See id. at 12.

${ }^{78}$ See Amar Gande \& Craig M. Lewis, Shareholder-Initiated Class Action Lawsuits: Shareholder Wealth Effects and Industry Spillovers, 44 J. FIn. \& QuANTITATIVE ANALYSIS 823, 829 (2009) (finding a lawsuit-related stock price decline of 9.79 percent).

${ }^{79}$ See, e.g., Peter L. Welsh et al., Cyan v. Beaver County: Implications Moving Forward, 32 Insights, Apr. 2018, at 7 (predicting companies will adopt federal forum provisions); DAvis Polk \& Wardwell LlP, The Supreme Court's Cyan Decision and What Happens NeXT (2018) ("[I]ssuers and potential issuers may attempt to respond to the Court's decision by updating their articles of incorporation with a clause stipulating that federal court will be the exclusive venue for all 1933 Act class actions"); Cleary GotTlieb SteEn \& Hamilton LlP, Supreme Court Holds That Securities Act Class Actions May Be Brought In StATE Court (2018) ("[C]ompanies may wish to consider adopting forum selection by-laws requiring Securities Act class actions to be filed in federal court"). 
SEC website. The full dataset includes 107 firms that adopted an exclusive forum provision in their charter or bylaws. Out of 107 firms, 72 adopted the provision in their charter, and the rest adopted it in the bylaws ${ }^{80}$ Adoption of the provision in the charter makes it harder for shareholders to repeal the provision, because only the board typically has the right to propose to amend the charter ${ }^{81}$ whereas shareholders have the right to initiate amendments to the bylaws. ${ }^{82}$ While there is some variation, a typical federal exclusive forum provision states: "Unless the Company consents in writing to the selection of an alternative forum, the federal district courts of the United States of America shall be the exclusive forum for the resolution of any complaint asserting a cause of action arising under the Securities Act of 1933." ${ }^{83}$ Whereas most firms seek to restrict lawsuits to federal courts generally, some firms go further by explicitly limiting the forum to the federal district court in the district in which they are incorporated, primarily Delaware,$^{84}$ or the district in which they are located.$^{85}$ Although the wording of the provision tends to be very similar across firms, there are also a few idiosyncratic provisions. ${ }^{86}$

Most of the firms adopted the provision in their IPOs, the first IPO firm being Snap, Inc. in February 2017. This is unsurprising, because most claims under the 1933 Act relate to misstatements or omissions in the prospectus or the registration statement filed prior to the IPO. Some firms adopted the provision in the context of a merger transaction in which the acquiring company issued and registered new shares. In fact, the first issuer that adopted the provision in September 2016, Lpath, Inc., was not an IPO firm. ${ }^{87}$

${ }^{80}$ Three firms adopted the provision in both the charter and bylaws.

${ }^{81}$ Compare Del. Code AnN., tit. 8, § 242(b)(1) (2018) (stipulating that "board of directors shall adopt a resolution setting forth the amendment" to the corporate charter), with id. $\S 109$ (a) ("the power to adopt, amend or repeal bylaws shall be in the stockholders entitled to vote . . ."); Lucian Arye Bebchuk, Limiting the Contractual Freedom in Corporate Law: The Desirable Constraints on Charter Amendments, 102 HARv. L. Rev. 1820, 1825-29 (1989) (explaining how directors wield greater bargaining power over shareholders in charter amendments, as they alone have the power to propose these amendments); Choi \& Min, supra note 4 (explaining how shareholders can propose amendments to bylaws, though most large corporations now allow directors to unilaterally amend them).

${ }^{82}$ See sources cited supra, note 81 .

${ }^{83}$ See, e.g., Snap Inc., Registration Statement (Form S-1) 43 (Feb. 2, 2017).

${ }^{84}$ See, e.g., Axonics Modulation Technologies, Inc., Amended and Restated Certificate of Incorporation (Exhibit 3.6) art. VIII, https://www.sec.gov/Archives/edgar/data/1603756/000 119312518303533/d609102dex36.htm.

${ }^{85}$ For a provision restricting jurisdiction to the district court for the district of Massachusetts, see Avrobio, Inc., Amended and Restated By-laws (Exhibit 3.5) art. VI § 8, https://www .sec.gov/Archives/edgar/data/1681087/000119312518188630/d562006dex35.htm.

${ }^{86}$ See, e.g., Graf Industrial Corp., Second Amended and Restated Certificate of Incorporation (Exhibit 3.2) art. XII, https://www.sec.gov/Archives/edgar/data/1745317/0001144204 18053781/0001144204-18-053781-index.htm ("the Court of Chancery of the State of Delaware shall be the sole and exclusive forum ... [except] any claim arising under the federal securities laws, as to which the federal district court for the District of Delaware shall be the sole and exclusive forum.").

${ }^{87}$ See Lpath, Inc., Amended and Restated Bylaws (Exhibit 3.1) art. XV, https://www.sec .gov/Archives/edgar/data/1251769/000110465916143729/0001104659-16-143729-index.htm. 
Because the adoption of federal exclusive forum provisions is mainly driven by IPO firms, we plot the likelihood that a firm adopts the provision in the IPO in Figure 1, shown in Appendix A. We compute this likelihood simply as the percentage of IPOs in a given month that adopted the provision out of the total number of IPOs that month, starting in February 2017 (when Snap, Inc. adopted the first provision). As is clear from the figure, Cyan and Sciabacucchi had a material impact on whether firms adopted federal exclusive forum provisions. Prior to the Cyan decision, there is a mild increase in the likelihood of adopting the provision. After Cyan, there is a large jump of over 10 percent in the likelihood of adoption, and an ongoing increase in this likelihood until the Sciabacucchi decision. After Sciabacucchi, however, there is a sharp decline of over 10 percent, and then a gradual decrease through June 2019. Presumably, some firms continued to adopt the provision with the hope that the Sciabacucchi decision would be reversed by the Delaware Supreme Court.

In Table 1, shown in Appendix B, we evaluate the characteristics of FFP-adopting firms at the IPO stage, and compare them to firms that did not adopt a FFP. We obtained data on IPO firms first from the SDC database and then matched it to financial data from Compustat. We obtained data on stock prices from CRSP and data on firm age from Professor Jay Ritter's website. Financial data is from the fiscal year ending prior to the year of the IPO. As already shown in Figure 1, most of the adoptions occurred in the period after the Cyan decision, but before the Sciabacucchi decision.

Importantly, adopting firms are more likely to belong to industries that are known to be particularly vulnerable to securities class-action litigation. Vulnerable industries include the biotechnology, computer hardware, electronics, retail, and computer software industries ${ }^{88}$ Specifically, over 70 percent of the adopting firms operate in the pharmaceutical, medical equipment or computer software industries.

The IPOs of adopting firms tend to be relatively large, as manifested by the relatively larger proceeds of these IPOs ("IPO Proceeds"). Somewhat more tellingly, these IPOs tend to be underpriced. In other words, while most companies see their stock price greatly increase on the first day of trading, the percentage increase is larger in our sample for firms with FFPs than for non-adopting firms. This is consistent with the hypothesis that adopting firms face a high probability of litigation, as earlier research suggests that firms with higher litigation probability are more likely to under-

${ }^{88}$ See Douglas J. Skinner, Earnings Disclosures and Stockholder Lawsuits, 23 J. Асcт. \& Econ. 249, 256 n.5 (1997); Jonathan L. Rogers \& Phillip C. Stocken, Credibility of Management Forecasts, 80 Acct. Rev. 1233, 1257 (2005); Francois Brochet \& Suraj Srinivasan, Accountability of Independent Directors: Evidence From Firms Subject to Securities Litigation, 111 J. Fin. ECON. 430, 448 (2014). 
price their issuances. ${ }^{89}$ Other variables further suggest that adopting firms may be more susceptible to lawsuits. In particular, these firms are more likely to have negative earnings, which could potentially induce investors to sue if the firm fails to generate income after the IPO, and also relatively higher levels of cash, which makes the firm a good target for lawsuits.

The governance of firms that adopt FFPs tends to be more shareholderfriendly than that of non-adopting firms. First, over 80 percent of them are backed by venture capital ("VC") or private equity ("PE") firms. Prior research has shown that the IPOs backed by VC or PE firms are more likely to exhibit a better governance structure, such as more independent boards..$^{90}$ Moreover, adopting firms are less likely to have a dual-class structure following the IPO. This suggests that these provisions are not driven by controlling shareholders seeking to protect themselves from potential liability.

Finally, virtually all of the adopting firms are incorporated in Delaware and over half are headquartered in California. This is unsurprising, given the high percentage of VC/PE-backed IPOs in the sample. More interestingly, we document the association between the retention of law firms that pioneered the use of FFPs and adoption rates. We construct a variable called Law Firm, which equals 1 if the firm retained one of three law firms: Cooley, Goodwin Procter and Wilson Sonsini. The companies that retained these law firms were more than six times more likely to adopt the provision.

In Table 2, we depict descriptive statistics of firms that were subject to lawsuits pursuant to Section 11 under the 1933 Act in from 1996 to 2018, and compare them to IPO firms that were not subject to such lawsuits. We obtained this data from the Stanford Law School's Securities Class Action Clearinghouse, which we matched to SDC data on IPOs as well as data from Compustat, CRSP and Jay Ritter's website (as applicable).$^{91}$ The characteristics that distinguish IPOs that are followed by a lawsuit seem to be very similar to those that characterize firms that adopt FFPs. Specifically, the firms tend to belong to industries that are vulnerable to litigation, they have larger IPO proceeds, they are more likely to have negative earnings and higher cash, they are more likely to be backed by VC or PE firms, and they are more likely to underprice their IPOs.

In Tables 3 through 5, we supplement the descriptive statistics with regression analysis. In Table 3, we estimate a logit model where the depen-

${ }^{89}$ See Michelle Lowry \& Susan Shu, Litigation Risk and IPO Underpricing, 65 J. FIN. Econ. 309, 330 (2002); Qing Hao, Securities Litigation, Withdrawal Risk and Initial Public Offerings, 17 J. CORP. FIN. 438, 446 (2011).

${ }^{90}$ See Yael V. Hochberg, Venture Capital and Corporate Governance in the Newly Public Firm, 16 Rev. Fin. 429 (2012) (finding that venture capital-backed IPOs had better corporate governance features); Viral V. Acharya et al., Corporate Governance and Value Creation: Evidence from Private Equity, 26 Rev. Fin. Stud. 368, 370 (2013) (showing that the human capital of private equity partners creates lasting value for shareholders of their portfolio companies).

${ }^{91}$ Note that the Stanford litigation data does not include information about Section 12 lawsuits, so our analysis is restricted to Section 11 litigation. 
dent variable is an indicator that equals 1 if a firm is subject to a Section 11 lawsuit, and zero otherwise. The marginal effects in such regressions reflect the percentage increase or decrease of changing the independent variable by one unit. As shown in columns 1 and 2, if a firm belongs to a vulnerable industry, then it is about 4 percent more likely to be subject to a Section 11 lawsuit. In addition, larger IPOs and firms with negative earnings are more likely to be sued. The coefficient on the cash ratio is not statistically significant, however, but this may be because the variable is highly correlated with other variables. ${ }^{92}$ In columns 3 and 4, we show that VC/PE-backed IPOs are more likely to be sued, and so are firms that underprice their securities in anticipation of potential lawsuits. ${ }^{93}$ Finally, as shown in column 5, younger firms are more likely to be sued. We note that in columns 3 to 5 , the coefficients on some variables, in particular vulnerable industries, are not statistically significant, presumably because they are highly correlated with other variables.

The main results of this analysis are in Table 4, where the dependent variable is an indicator that equals 1 if a firm adopted an exclusive FFP, and zero otherwise, and the sample is restricted to the period of 2017 to 2019, when firms started adopting FFPs. As shown in column 1, a firm in an industry which is vulnerable to litigation is about 16 percent more likely to adopt the provision. Moreover, after Cyan, firms are about 16 percent more likely to adopt the provision, and after Sciabacucchi, the probability decreased by almost 9 percent (16.4 percent minus 7.7 percent). The results numerically confirm the general trends suggested by the pattern of adoption depicted in Figure 1. Column 2 shows that firms with high levels of cash or negative earnings are more inclined to adopt the provision. Specifically, firms with negative earnings are about 12 percent more likely to adopt the provision.

In column 3, we add governance measures to the regression. We find that the IPOs that are backed by VC or PE firms are about 14.4 percent more likely to adopt the provision, and that firms with a dual class stock structure are 8.7 percent less likely to adopt it. Interestingly, in this specification, the association of vulnerable industries, negative earnings, and cash becomes statistically insignificant. The likely reason for this is that many of these variables are correlated with investments by venture capital firms that tend to invest in high-growth firms with lower earnings.

Column 4 shows that firms incorporated in Delaware and headquartered in California are substantially more likely to adopt the provision. Moreover, as expected, companies that retained one of the three innovating law firms (Cooley, Goodwin Procter, or Wilson Sonsini) were 15 percent more likely

\footnotetext{
${ }^{92}$ In particular, cash ratio is highly positively correlated with firms belonging to vulnerable industries.

${ }^{93}$ This is consistent with Lowry \& Shu, supra note 89 (finding that firms with higher exposure to Section 11 lawsuits are more likely to underprice their offerings); cf. Hao, supra note 89 (finding no relationship between underpricing and the probability of lawsuits).
} 
to adopt the provision. We emphasize again, however, that these additional variables are highly correlated with other variables and likely endogenous, because they are variables chosen by the firms. For example, we would expect a venture-backed biotechnology firm located in California to retain Cooley, incorporate in Delaware, and have low earnings in its early years. In column 5, we add the age variable, which suggests that younger firms are more likely to adopt the provision. However, the coefficient on the age variable is not statistically significant.

In Table 5, we link the probability of adopting FFPs to the estimated probability of litigation based on the estimates presented in Table 3. We compute the predicted probability of getting sued using the coefficient estimates from column 5 in Table 3 (though the results are robust to using the specifications in other columns). We show that the probability of adopting an FFP is higher when the probability of litigation is higher. The results imply that one standard deviation in predicted litigation probability (which is 6.2 percent) is associated with a 7.4 to 12.1 percent higher likelihood of adopting an FFP (depending on the specification). In columns 2 and 3, we add variables not used in computing the litigation probability (i.e., those not included in column 5 of Table 3). The results confirm that firms with dualclass stock structures are less likely to adopt FFPs, and that adoption is driven in part by specific law firms that pioneered the use of FFPs.

\section{Measuring the Effect of Sciabacucchi on Firm Value}

In this Part, we empirically examine the impact of Sciabacucchi. We focus on the firms that have adopted an FFP in their organizational documents, and see whether the Sciabacucchi decision had any discernable effect on their stock prices. Although various commentators have argued the importance of FFPs, whether it would indeed have any significant effect on a firm's valuation has been open to debate. Using the event study methodology, we attempt to examine the magnitude of the effect.

\section{A. Data and Empirical Strategy}

We obtain data on securities returns from the Center for Research in Security Prices ("CRSP"). ${ }^{94}$ In Figure 2, we plot the average returns of the firms that had an exclusive forum provision around the date that Sciabacucchi was decided (December 19, 2018). We compare these returns to the return on the market portfolio, which is the value-weight return of all public firms available on CRSP, incorporated in the US, and listed on the NYSE, AMEX, or NASDAQ.${ }^{95}$ As is apparent in Figure 2, the sample firms

\footnotetext{
${ }^{94}$ Returns are equal to today's price plus any dividends, divided by yesterday's price.

${ }^{95}$ See Kenneth R. French, U.S. Research Returns Data, http://mba.tuck.dartmouth.edu/ pages/faculty/ken.french/data_library.html\#Breakpoints.
} 
experienced lower returns around the date of the decision as compared to the market portfolio, specifically in the period starting two days before the decision (December 17, 2018) and ending two days afterwards (December 21, 2018). This suggests that Sciabacucchi had a negative effect on the sample firms.

The fact that Sciabacucchi was a significant event is further supported by anecdotal evidence. Thirty firms in the sample reported the decision in 8Ks in order to inform the market that the company did not intend to enforce the provision due to the Sciabacucchi decision, ${ }^{96}$ and some even announced their intention to remove the provision at the next annual meeting if the decision was not appealed or if the Delaware Supreme Court affirmed the Chancery Court's decision. ${ }^{97}$

We use event study methodology to evaluate the stock price effect of the Sciabacucchi decision. The first is a standard event study. The underlying assumption of event studies is that markets are efficient, so when a case is decided, stock prices reflect the news..$^{98}$ The first step in an event study is to define the event of interest and the date or dates when the market learned about or anticipated the event. We define the day when Sciabacucchi was decided as event date 0 . We focus on the period starting two business days prior to the date of the decision and two business days after the decision (i.e., event window $(-2,+2)$ ), but we also examine the period starting seven trading days prior to the decision and ending seven days after the decision (i.e., from December 10, 2018 to December 31, 2018). In particular, because the market may be familiar with the views of Delaware judges on broad policy matters, and given that Delaware judges tend to be vocal on such matters, it is possible that the market could anticipate a decision a few days before it is announced. ${ }^{99}$ In addition, it may take a few days for investors to be fully informed about a decision and its full ramifications. The first 8 -K reporting the Sciabacucchi decision by Snap Inc. was filed on December 21, two days after the decision. ${ }^{100}$

The next step is to estimate what the expected return for each stock would have been during the event period if the event had not occurred (i.e., if Sciabacucchi had not been decided). The abnormal return that is attributable to the event (i.e., the stock price effect of the event) is the actual return

${ }^{96}$ See, e.g., Snap Inc., Current Report (Form 8-K) (Dec. 21, 2018).

${ }^{97}$ See, e.g., Arlo Technologies, Inc., Current Report (Form 8-K) (Dec. 31, 2018).

${ }^{98}$ For detailed descriptions of the event study methodology, see generally Sanjai Bhagat \& Roberta Romano, Event Studies and the Law:Part I: Technique and Corporate Litigation, 4 Am. L. \& Econ. Rev. 141 (2002); Sanjai Bhagat \& Roberta Romano, Event Studies and the Law: Part II: Empirical Studies of Corporate Law, 4 AM. L. \& Econ. Rev. 380 (2002); A. Craig MacKinlay, Event Studies in Economics and Finance, 35 J. Econ. Lit. 13 (1997).

${ }^{99}$ See S.P. Kothari \& Jerold B. Warner, Econometrics of Event Studies, 1 HandBooK of Corporate Finance 3, 10 (Bjørn Espen Eckbo ed., 2008) ("[I]f the event is partially anticipated, some of the abnormal return behavior related to the event should show up in the preevent period.").

${ }^{100}$ See supra note 88. 
minus the expected return. To compute the expected return on the event window, we use the Carhart four-factor model in our main specifications:

$$
R_{i t}=a_{i}+\beta_{M T} R_{M T}+\beta_{S M B} R_{S M B}+\beta_{H M L} R_{H M L}+\beta_{M O M} R_{M O M}+\varepsilon_{i t}
$$

where $R_{i t}$ is the return on stock $i$ on date $t$ minus the risk free rate; $R_{M T}$ is the market return on date $t$ minus the risk free rate; $R_{S M B}$ is the return on a portfolio of small companies; $R_{H M L}$ is the book-to-market factor, which is the portfolio of firms with high book value to market value ratio; $R_{M O M}$ is the momentum factor, which is the return on stocks that experienced positive returns in the prior 12 months; and $\varepsilon_{i t}$ is an error term, common to all regression models. ${ }^{101}$ We estimate other alternative models, including the market model, the three-factor Fama-French model and the five-factor Fama-French model. 102

This regression yields estimated parameters $\widehat{\alpha}, \widehat{\beta_{M T}}, \widehat{\beta_{S M B}}, \widehat{\beta_{H M L}}$ and $\widehat{\beta_{M O M}}$, which we then use to calculate the expected return on the event date. This equals $\hat{\alpha}_{i}+\hat{\beta}_{M T} R_{M T}+\hat{\beta}_{S M B} R_{S M B}+\hat{\beta}_{H M L} R_{H M L}+\hat{\beta}_{M O M} R_{M O M}$, using the factor portfolios' returns on the event days. The abnormal return for a given event date, $A R_{i t}$, for stock $i$ is then simply the actual stock return minus the expected stock returns:

$$
A R_{i t}=R_{i t}-\hat{\alpha}_{i}-\hat{\beta}_{M T} R_{M T}-\hat{\beta}_{S M B} R_{S M B}-\hat{\beta}_{H M L} R_{H M L}-\hat{\beta}_{M O M} R_{M O M} .
$$

To estimate the impact of an event within a specific event window, we need to aggregate the abnormal returns across all days in the event window to obtain the cumulative abnormal returns. Thus,

$C A R_{i t}=\sum_{t_{0}}^{t_{n}} A R_{i t}$,

where $\mathrm{t}_{0}$ is the first event day and $t_{\mathrm{n}}$ is the last event day. The average $C A R_{i t}$ across all firms $i$ in the sample is the average cumulative abnormal return associated with the event. Note that if the event window includes only the event day, we simply compute the average abnormal return on the event date across firms.

In estimating the regression model in equation 1 , we use observations from an estimation window of 120 trading days, starting eight trading days prior to December 19 (i.e., day -127 to -8). Note, however, that because our sample includes many firms that underwent an IPO in a very recent period, not all firms have trading data for the full estimation window. In our main specification, we require firms to have at least 50 trading days in order to be included in the model. In this specification 65 firms are included in the final

${ }^{101}$ For fuller explanation of each factor, see Mark M. Carhart, On Persistence in Mutual Fund Performance, 52 J. FIN. 57, 60-61 (1997).

${ }^{102}$ Each of these models is explained in further detail in Kothari \& Warner, supra note 99. 
sample. We also estimate the model using other thresholds, specifically 40 , 60 , or 80 days.

One concern with an event study of a single event is that the abnormal returns for the firms during the event window could be correlated with each other. ${ }^{103}$ To address this concern, we employ portfolio analysis as an alternative specification. In this specification, the dependent variable is the return on the portfolio of equally weighted stocks of the firms that adopted exclusive forum provisions, and the independent variables are the factor portfolios:

$$
\begin{gathered}
R_{p t}=a+\beta_{M T} R_{M T}+\beta_{S M B} R_{S M B}+\beta_{H M L} R_{H M L}+ \\
\beta_{M O M} R_{M O M}+A R \times D_{t}+\varepsilon_{i t},
\end{gathered},
$$

where $R_{p t}$ is the return on the equally weighted portfolio of all the firms in our sample, and $D_{t}$ is an indicator variable equal to 1 if a date $t$ is within the relevant event window. In this specification, the estimated coefficient on $D_{t}$ $\widehat{\mathrm{AR}}$, is equal to the average abnormal return of the firms in the portfolio associated with each day within the relevant event window. The cumulative abnormal return then equals the number of days in the event window times $\widehat{\mathrm{AR}}$. For example, if $D_{t}$ equals one for three event days (say, $-1,0$ and +1 ), then the average CAR equals three times the estimated abnormal return $(\widehat{\mathrm{AR}})$.

\section{B. Results}

We first show the results estimating equation (1). Using that equation, we compute the abnormal returns for each of the event dates from day -7 to day +7 . We depict the average abnormal returns for each of these days in Figure 3 . The results suggest that the stock price of the firms in our samples exhibit smaller abnormal returns on event days -2 to +2 . The abnormal returns before this event window from -7 to -3 , and after the event window from +3 to +7 , do not seem to yield any clear patterns, although it is noteworthy that the abnormal returns in the days before -2 appear to be lower than those after +2 .

Table 6 shows the cumulative abnormal return associated with different event windows. In column 1 , we report first the average abnormal returns for day 0 , which is -1.82 percent, although it is statistically significant only at the 10 percent level. The results for wider event windows appear to be larger and more statistically significant. Thus, the effect associated with event windows $(0,+1),(0,+2),(-1,+1)$, and $(-2,+2)$ are -3.15 percent, -4.73 percent, 4.18 percent, and -7.43 percent, all statistically significant at the 1 percent

${ }^{103}$ See James W. Kolari \& Seppo Pynnönen, Event Study Testing with Cross-Sectional Correlation of Abnormal Returns, 23 Rev. Fin. STUd. 3996 (2010). 
level. Note that the cumulative abnormal returns associated with the period $(-7,-3)$ or the period $(+3,+7)$ are not statistically significant.

In Table 7, we show the results from estimating the model in equation (2). The results of this model are even stronger and are broadly consistent with our main results. Column 1 indicates that the average abnormal return associated with event date 0 is -1.83 percent (and is statistically significant at the 5 percent level). Columns 2 through 5 show that the abnormal returns associated with the event dates within each event window are between -1.39 percent and -1.57 percent. Multiplying these coefficients by the number of days in the relevant window, the cumulative abnormal returns implied by the estimated coefficients are essentially the same as under equation 1. Finally, in column 6 , we also estimate the abnormal returns for event windows $(-7,-$ $3)$ and $(+3,+7)$. The results again suggest that there are no abnormal returns associated with these days. Accordingly, the firms in our sample appear to experience an abnormal stock price effect only around the Sciabacucchi decision.

In Tables 8 and 9, we further look at the stock price effects on specific types of firms. In Panel A, we look at firms that belong to industries identified in prior research as being prone to securities class action litigation. These include firms in the biotechnology, computer hardware, computer software, electronics, and retail industries. All the results for these firms are more economically and statistically significant than for the total sample. The cumulative abnormal returns around the event window $(-2,+2)$ is almost 10 percent, suggesting that the case had a very large negative effects on these firms.

In Panel B, we examine only firms that adopted the exclusive FFP in their charters. Whereas shareholders have the right to amend the bylaws, only the board of directors has the right to initiate amendments to the charter. ${ }^{104}$ This arguably means that these provisions may be stickier, and it may be more difficult for shareholders to amend them if they are not conducive to shareholder value. The results are broadly robust to this specification, though they tend to be less statistically and economically significant. The abnormal return of -1.37 percent on date 0 is not statistically significant using the model in equation 1 (see column 1 of Table 8, Panel B). There is an abnormal return of -1.39 percent that is statistically significant at the 10 percent level using the model in equation 2 (see column 1 of Table 9, Panel B). However, it is likely that the lower significance is mainly due to the fact that this sample includes only 42 firms, and, in any event, the negative effect in other event windows remains substantial; and at least in Table 9, statistically significant at the 5 percent or 1 percent levels for all other event windows.

In Panel D, we exclude IPO firms with a dual-class stock structure. The remaining firms are arguably the better firms, because they are less prone to agency problems and therefore may arguably be expected to be less affected

${ }^{104}$ See Bebchuk, supra note 81. 
by the Sciabacucchi decision and litigation more broadly. However, as in Panel A, all the results for these firms are more economically and statistically significant than for the total sample, even though the total sample is smaller.

In Panel E, we examine firms that underpriced their securities at the IPO. It is therefore likely that investors in these firms made gains by buying securities in the IPO. The results are again robust as to this specification. In Panel F, we evaluate firms with a share price higher than the IPO price at date -3 . This means that as of the date of Sciabacucchi, if the shareholders were to file a Section 11 lawsuit on that day, they would have gained nothing, since they would have been unable to show any harm (damages) from alleged misrepresentations or misstatements. ${ }^{105}$ Although the sample includes only 28 firms, the results are again robust and even more economically significant for some event windows.

Finally, we emphasize that our results are robust using other asset pricing models, specifically, the market model and the Fama-French three or five factor models. The results are also robust when we include firms that have only 40 trading days in the estimation window, or alternatively, at least 60 , 70 , or 80 days in the estimation window.

\section{IMPLicAtions of the EMPIRICAL Results}

In this Part we discuss the main implications of the empirical results. First, firms with a high probability of facing IPO-related lawsuits are more likely to adopt FFPs, and it is difficult to argue that the adoption is driven by firms with more serious agency problems. This suggests that the firms that choose to adopt FFPs may not necessarily be the "bad apples," but rather firms that are more likely to be targeted by plaintiffs. ${ }^{106}$ The vast shift of Section 11 lawsuits from federal courts to state courts indicates that plaintiffs, likely influenced by their lawyers, are looking to evade the more demanding requirements imposed by the PLSRA and federal pleading standards. Firms that adopt FFPs want to protect themselves from the possibility that the firm will be embroiled in unnecessary litigation, and might have to settle just to get rid of lawsuits that may take place in state courts that have limited expertise and experience in securities litigation.

Second, the Sciabacucchi decision is associated with a high negative stock price effect, and the effect persists for firms with arguably lower agency costs and for firms that are less likely to pay any damages in Section 11 lawsuits (either because their stock was priced relatively low at the IPO or because their stock was trading at a higher price than the IPO price prior

${ }^{105}$ As discussed supra note 19, if the company's share price is above the IPO price at the time the plaintiff files a lawsuit, she gets nothing in Section 11 damages.

${ }^{106}$ Of course, we cannot overrule the possibility that there is some unobserved fraudulent intent associated with adopting FFPs. 
to the Sciabacucchi decision). We note, however, that the magnitude of the stock price effect, amounting to more than 7 percent for the event period ($2,+2)$, appears to be very high. Taken at face value, this suggests that the decision reduced the total market capitalization of a firm with an FFP by 7 percent. ${ }^{107}$ It is thus questionable whether we can attribute all of this effect to the Sciabacucchi decision. As in any event study, there is always a possibility that something else may have happened around the event window that may have affected the stock price of the firms in our sample.

However, even if there are other events that may confound the effect of the decisions, the size of the stock price effects strongly suggests that, at the very least, it is safe to rule out the possibility that Sciabacucchi positively affected the stock price of firms that adopted FFPs. Moreover, given the very high negative stock price effect of shareholder class action litigations (valued by one study at almost 10 percent), ${ }^{108}$ and the impact that litigating in state court as opposed to federal court has on litigation outcomes (discussed in Part II), it may be argued that the negative stock price effect does actually reflect the negative impact of Sciabacucchi on firm value.

That said, there is a concern that the decline in stock prices may simply reflect the higher likelihood that firms will have to pay large amounts in settlements from their own funds, rather than reflecting the desirability of these provisions. However, we emphasize that the negative stock price effect seems very high compared to the typical settlement amounts. The higher probability of obtaining recovery in a settlement if a claim in federal court is also litigated in a state court as opposed to litigated only in state court (83 percent compared to 59 percent), multiplied by the average settlement amounts in Section 11 lawsuits (about $\$ 10$ million), ${ }^{109}$ is well below the loss in market value observed in the event study, whichever event window we use. A likely explanation is that the negative effect of litigation does not only reflect the likely recovery amounts, but rather mainly reflects the impact of litigation on the firm's reputation and goodwill, ${ }^{110}$ and the concern that protracted litigation could distract managers from pursuing valuable

${ }^{107}$ In general, large stock price effects may be partly driven by thinly-traded stocks with very low prices. When the stock price is low (for example, below one dollar) or the volume of trading is low, any small changes in the price or a small number of trades can generate large shifts in stock returns. However, we emphasize that the relatively large stock price effect is not driven by low stock prices or trading volume. All the firms in our sample are listed on the New York Stock Exchange or Nasdaq, and the price of the stock at the IPO is at least five dollars. Moreover, even when we exclude five firms whose stocks traded below three dollars or whose trading volume was below 1,000 stocks on the date Sciabacucchi was decided, the results are qualitatively the same.

${ }^{108}$ See Gande \& Lewis, supra note 78 , at 8.

${ }^{109}$ See Klausner et al., supra note 45, at 11.

${ }^{110}$ See, e.g., Jonathan M. Karpoff \& John R. Lott, Jr., The Reputational Penalty Firms Bear from Committing Criminal Fraud, 36 J.L. \& Econ. 757 (1993) (arguing that the reputational cost constitutes most of the cost incurred by firms accused and convicted of fraud); Edward B. Rock, Saints and Sinners: How Does Delaware Corporate Law Work?, 44 UCLA L. Rev. 1009 (1997) (recasting Delaware corporate law as a series of reputational as well as financial constraints on managers to make them work in the shareholders' interests). 
projects and divert corporate resources to dispute resolution. ${ }^{111}$ This is consistent with the high negative stock price effect associated with the filing of securities class action litigations, which also substantially exceeds the potential recovery amounts. ${ }^{112}$

\section{Sciabacucchi and the Delaware Supreme Court's Reversal}

While the results of the empirical analysis are not dispositive, they generally lend some support to the view that the FFPs are desirable and do not undermine shareholders' rights. The most straightforward policy response to address this may be to reform the 1933 Act or SLUSA to restrict these lawsuits to federal courts, the path taken by the jurisdictional rules under the 1934 Act. ${ }^{113}$ However, Congress may be slow to act, and there may not be sufficient political support for reforming the federal law. Furthermore, it still leaves open the question of to what extent a corporation's organizational documents can regulate federal issues, such as the 1933 Act claims. Accordingly, it may be worth examining the legal basis of Sciabacucchi to evaluate whether or not there is a plausible legal theory that can justify the opposite outcome of validating FFPs in charters and bylaws. More broadly, reexamining Sciabacucchi is an opportunity to evaluate the scope of existing corporate law doctrines on internal affairs and corporate contract.

We emphasize that we do not claim that the legal basis of Sciabacucchi is unfounded. There is a legitimate argument that a claim based on the 1933 Act is not a claim that deals with the "internal affairs" of a corporation and, furthermore, charters or bylaws can only deal with matters that relate to the "internal" affairs. For instance, Boilermakers can be understood to stand for the proposition that a forum selection provision is valid if it regulates "internal affairs claims brought by stockholders qua stockholders." 114 In line with this reasoning, Sciabacucchi held that claims under the 1933 Act are "external" to the corporation's affairs. The cause of action under the 1933 Act belongs to a "security" purchaser, including securities other than stocks, rather than to stockholders, who already own shares in the corporation. Boilermakers, by contrast, validated forum selection provisions that related to

${ }^{111}$ See Janet Cooper Alexander, Do the Merits Matter? A Study of Settlements in Securities Class Actions, 43 Stan. L. Rev. 497, 571 (1991) (citing the foregone business time managers need to spend on the litigation as a major indirect cost of securities litigation); see also Joy v. North, 692 F.2d 880, 892 (2d Cir. 1982) (stating "key personnel may be distracted from corporate business by continuance of the litigation").

${ }^{112}$ Gande \& Lewis, supra note 78.

113 15 U.S.C. § 78aa (2018); see supra note 22.

${ }^{114}$ Boilermakers Local 154 Ret. Fund v. Chevron Corp., 73 A.3d 934, 952 (Del. Ch. 2013). 
lawsuits under Delaware corporate law, such as derivative litigation and lawsuits asserting breach of fiduciary duties. ${ }^{115}$

As is clear from the description of Boilermakers and Sciabacucchi, there are two important issues that need to be resolved in order to answer whether a charter or a bylaw provision can dictate shareholders' right to bring a 1933 Act claim in a specified forum. ${ }^{116}$ The first deals with the question as to what extent a charter or a bylaw provision can deal with issues that are "external" (or "not internal") to the affairs of a corporation. That is, if we determine or assume that a 1933 Act claim is an "external" claim, i.e., it does not deal with the internal affairs of a corporation, does that mean that the charter or the bylaws can no longer dictate or regulate its forum? This issue touches more broadly upon the question regarding the scope of the contractarian theory that courts have been utilizing with respect to corporate charters and bylaws. The second issue has to do with the boundaries of the internal affairs doctrine itself. Can we argue that a 1933 Act claim can be treated as an "internal," rather than an "external" claim?

In addressing these issues, two sets of Delaware General Corporation Law ("DGCL") provisions play a prominent role. The first is DGCL $\S 102$ (b)(1), together with $\S 109$ (b), and the second is DGCL $\$ 115$. DGCL $\S 102$, titled "Contents of Certificate of Incorporation," which lays out types of matters that can be addressed through a charter or bylaws. More specifically, DGCL §102(b) states that:

the certificate of incorporation may also contain any or all of the following matters: (1) Any provision for the management of the business and for the conduct of the affairs of the corporation, and any provision creating, defining, limiting and regulating the powers of the corporation, the directors, and the stockholders. . . .

Similarly, DGCL §109(b), which deals with the contents of the bylaws, states that: "the bylaws may contain any provision, not inconsistent with law or with the certificate of incorporation, relating to the business of the corporation, the conduct of its affairs, and its rights or powers or the rights or powers of its stockholders, directors, officers, or employees. . .."117

While DGCL $\S \S 102$ and 109 deal fairly broadly with the permissible matters that can be addressed through charters and bylaws, DGCL $\S 115$, by

${ }^{115}$ Furthermore, both Boilermakers and Sciabacucchi can be understood to stand for the proposition that the right to sue under the 1933 Act in any specific court cannot be waived or modified through the charter or the bylaws.

${ }^{116}$ There also is a third, ancillary issue: how and whether to make the interpretations of the relevant statutory provisions, i.e., DGCL $\$ \S 102(b), 109$ (b), and 115, consistent with one another. As shown below, while DGCL $\S \S 102(\mathrm{~b})$ and 109(b) speak of "affairs" of corporation, DGCL $\$ 115$ provides an express definition of "internal affairs." One can argue that when the statute mentions "affairs," they mean "internal affairs."

${ }^{117}$ Finally, DGCL $\S 102(\mathrm{~b})(1)$ also states that "any provision which is required or permitted by any section of this chapter to be stated in the bylaws may instead be stated in the certificate of incorporation." 
contrast, deals more specifically with forum selection provisions. The section states:

The certificate of incorporation or the bylaws may require. . that any or all internal corporate claims shall be brought solely and exclusively in any or all of the courts in this State, and no provision of the certificate of incorporation or the bylaws may prohibit bringing such claims in the courts of this State. "Internal corporate claims" means claims, including claims in the right of the corporation, (i) that are based upon a violation of a duty by a current or former director or officer or stockholder in such capacity, or (ii) as to which this title confers jurisdiction upon the Court of Chancery.

In short, DGCL $\$ 115$ allows a charter of a bylaw provision to dictate that an "internal corporate claim" to be brought "in any or all of the courts" of Delaware, but does not allow such claims to be brought solely in non-Delaware courts.

\section{A. The Boundaries of the Corporate Contract}

Here we address the first question concerning the extent to which a charter or a bylaw provision can deal with claims that are not "internal" corporate claims. Suppose, for the sake of the argument, that we agree that a 1933 Act claim is not an internal corporate claim, as defined in DGCL §115. The first obvious implication of this assumption is that, given that DGCL $\$ 115$ deals only with "internal corporate claims," a 1933 Act claim will no longer be subject to the DGCL $\S 115$ requirements. At the same time, however, that conclusion does not necessarily prevent charters and bylaws from adopting an exclusive forum clause for an "external" claim. Note, foremost, that both DGCL $\S 102(b)(1)$ and $\S 109(b)$ are written fairly broadly. In the case of $\$ 102(b)(1)$, for instance, a charter provision can address not only the "the conduct of the affairs of the corporation," it can also "creat[e], limit[ ] and regulat[e] the powers of the corporation, the directors, and the stockholders."

One possible interpretation of the statute is to say that while a federal forum provision does not deal with an "internal" corporate claim, it does "regulate" or "limit" the "powers . . of the stockholders," i.e., their power to bring a 1933 Act suit as stockholders, and does also deal with the "affairs" of the corporation, i.e., whether and how certain disclosures should be made to the stockholders under both federal securities and corporate laws. After all, one can argue that, as stockholders, they are given a bundle of rights, including those under both the state corporate law and federal securities law, and thus when they bring a 1933 Act claim, they are exercising 
their powers as stockholders (investors). ${ }^{118}$ What the federal forum provision does is then to "limit" or "regulate" their rights or powers (as stockholders) to bring a 1933 Act claim.

More fundamentally, this approach would expand the reach of the contractarian perception of charters and bylaws, the so-called "corporate contract." 119 The idea that the charters and bylaws can be treated like a "contract" played an extremely important role in Boilermakers. For instance, the Chancery Court stated: "in an unbroken line of decisions dating back several generations, our Supreme Court has made clear that the [charters and] bylaws constitute a binding part of the contract between a Delaware corporation and its stockholders." 120

The Chancery Court relied, in part, on Justice Strine's earlier articulation of Delaware corporate law more generally:

Delaware's corporation law is not what . . . might be called a broad-based company law. Aspects of company law like competition law, labor law, trade, and requirements for the filing of regular disclosure to public investors, are not part of Delaware's corporation law ... Delaware corporation law governs only the internal affairs of the corporation (emphasis added). In that sense, our law is a specialized form of contract law that governs the relationship between corporate managers-the directors and officers-of corporations, and the stockholders. ${ }^{121}$

Therefore, Sciabacucchi espouses a narrow view with respect to both corporate law and corporate contract. But, of course, this is not the only possible interpretation of corporate law and corporate contract. Other commentators have argued that, with respect to other issues, Delaware corporate law (and the corporate contract) already regulates matters that technically fall outside

118 This argument is further buttressed by the fact that DGCL $\$ 102(b)$ uses the phrase "affairs of the corporation" and not "internal affairs of the corporation." Hence, under $\S 102$ (b), "affairs of the corporation" also includes non-internal affairs, such as stockholders' rights under federal securities laws. Instead of using "external" versus "internal" distinction, some commentators have used the phrase "intra-corporate" claims to denote those that deal with the "affairs" of corporation. See, e.g., Joseph A. Grundfest \& Kristen A. Savelle, The Brouhaha Over Intra-Corporate Forum Selection Provisions: A Legal, Economic, and Political Analysis, 68 Bus. LAw. 325 (2013). Under this approach, one can argue that DGCL $\S 102$ (b) allows corporations to put in provisions in their charters and bylaws so long as they deal with "intra-corporate" matters, even if, technically, the issue may fall outside of corporate law.

${ }^{119}$ For an overview of the development and the application of the "contractarian theory" of corporate charters and bylaws, see Choi \& Min, supra note 4.

${ }^{120}$ Boilermakers Local 154 Ret. Fund v. Chevron Corp., 73 A.3d 934, 955 (Del. Ch. 2013).

${ }^{121}$ Id. (quoting Leo E. Strine, Jr., The Delaware Way: How We Do Corporate Law and Some of the New Challenges We (and Europe) Face, 30 DEL. J. CoRp. L. 673, 674 (2005). The article is based on a speech given by then-Chancellor Strine to the European Policy Forum. In arguing that Delaware corporate law is meant to apply narrowly, however, there does not seem to be any citation to existing case law or other doctrines. 
a narrow understanding of corporate law, but are closely related to corporate law problems, such as stockholders' right to transfer or sell securities and debt-holders' and other non-corporate claimants' rights to bring claims against a liquidating corporation. ${ }^{122}$ As we demonstrate below, Delaware corporate law, in conjunction with the federal securities laws, also regulates the proxy process. ${ }^{123}$

In fact, this seems to be the reasoning adopted by the Delaware Supreme Court when it over-turned the Chancery Court's decision in Salzberg v. Sciabacucchi. ${ }^{124}$ The Court focused heavily on the statutory language of DGCL §102(b) and contrasted that with the language in DGCL §115. In the process, the Court held that the matters that relate to stockholders' right to sue under the federal Securities Act, while not part of internal affairs, can be classified as "intra-corporate" affairs and, therefore, be regulated through charters and bylaws. ${ }^{125}$

If we were to adopt a more expansive notion of the corporate contract (and also the corporate law more generally), as the Court did in Salzberg $v$. Sciabacucchi, given that FFPs will no longer be subject to the restrictions in DGCL $\S \S 109$ and 115 , it follows fairly naturally that Delaware corporations may not be able to adopt other non-Delaware forums to resolve 1933 Act disputes. They may even attempt to adopt a mandatory, individual arbitration provision for 1933 Act claims. A fee-shifting provision (perhaps even similar to the version we saw in ATP Tour Inc. v. Deutscher Tennis Bund $\left.{ }^{126}\right)$ with

${ }^{122}$ See Grundfest, supra note 39, at 65 (arguing that DGCL $\$ 202(c)(5)$, for instance, allows charters to impose transfer restrictions and securities ownership). In the asset sale and liquidation provisions, DGCL $\$ \S 271$ to 285 , Delaware corporate statute closely regulates the rights of various non-stockholders, such as debtholders, contract claimants, contingent claimants, etc., with respect to issues, such as whether and when they are entitled to receive notice, how they may be able to exercise their right against a dissolving and liquidating corporation, how much they would be entitled to receive, and whether they can impose liability on the directors or the shareholders that receive liquidating distribution.

${ }^{123}$ See infra Part VI.2.

${ }^{124}$ Salzberg v. Sciabacucchi, 2020 Del. LEXIS 100 (Del. 2020).

${ }^{125} \mathrm{Id}$. at 28-35. As a matter of policy, the fact that both the state and the federal laws can regulate over a certain issue does not tell us what the proper division of labor should be. Perhaps with respect to certain issues (e.g., some issues closer to market regulation), federal securities law should take the lead (or perhaps be the sole authority), whereas with respect to certain other issues (e.g., those that are just outside the boundary of internal affairs), the regulatory power should belong to the state corporate law. This is an important policy issue that is beyond the scope of this paper.

${ }_{126} 91$ A.3d 552 (Del. 2014). In that case, plaintiffs brought both corporate and antitrust claims against the defendant non-profit corporation and the Delaware Supreme Court upheld the facial validity of the defendant's fee-shifting provision (seemingly) against both types of claims. This opened the door for the possible interpretation that the charter and bylaws can also regulate non-corporate (in this case, antitrust) claims, the view that the Delaware Supreme Court relied on in Salzberg v. Sciabacucchi, 2020 Del. LEXIS 100, 23-28 (Del. 2020). See generally Albert H. Choi, Fee-Shifting and Shareholder Litigation, 104 VA. L. REv. 59 (2018) (discussing why ATP Tour's heavily one-sided fee-shifting is undesirable and arguing for more balanced fee-shifting). 
respect to 1933 Act claims is also a possibility. ${ }^{127}$ Some may argue that this is an unattractive byproduct of an expansive notion of corporate contract. We do not take a view in this Article on mandatory arbitration provisions, in large part because it is impossible to empirically evaluate their use and efficacy. However, we do emphasize that, at least as a matter of policy, it does not follow that validating FFPs should also lead to validating mandatory arbitration provisions that can preclude shareholders from filing lawsuits altogether. After all, even if FFPs are upheld, shareholders are free to bring their 1933 Act claims in federal court, either individually or as a class action.

A mandatory individual arbitration provision, on the other hand, not only denies the shareholders' right to bring a claim in (any) court, but may also vitiate their right to bring a class action claim. While charters and bylaws are not formal "contracts," even under the Federal Arbitration Act, mandatory arbitration provisions may be unenforceable when there are grounds in equity for the revocation of such agreements. ${ }^{128}$ It is possible that such provisions in the corporate law context will be viewed as unconscionable, for example, because shareholders do not typically have the opportunity to assent to provisions in the charter or bylaws. ${ }^{129}$ It may be argued that

${ }^{127}$ One may go even further. For instance, while the federal courts have the exclusive jurisdiction with respect to claims arising under the 1934 Exchange Act (claims, for instance, alleging material misstatement or misrepresentation in a company's periodic filings), under the Salzberg reasoning, such claims can be thought of as also belonging to the "intra-corporate affairs" and be regulated through charters and bylaws. For instance, a charter or a bylaw provision may dictate that such claims must be brought only in the federal district court of Delaware. They may also be inclined to include a fee-shifting provision. It is not entirely clear whether either of these will be in violation of PSLRA. Corporations may attempt to regulate other non-corporate and non-securities claims as well. For instance, in ATP Tour, the plaintiffs brought an antitrust claim against the defendant corporation. To the extent that such a claim relates to the matter between the corporation and its shareholders, one could conceive of a similar charter or a bylaw provision. Whether or not the law should allow corporations to dictate the forum (or impose fee-shifting) on issues that are not "internal" to the corporation raises more fundamental policy questions.

${ }^{128}$ Section 2 of the Federal Arbitration Act permits arbitration agreements to be declared unenforceable "upon such grounds as exist at law or in equity for the revocation of any contract." 9 U.S.C. $\$ 2$ (2018). This saving clause permits agreements to arbitrate to be invalidated by "generally applicable contract defenses, such as fraud, duress, or unconscionability." Doctor's Associates, Inc. v. Casarotto, 517 U. S. 681, 687 (1996); see also Perry v. Thomas, 482 U. S. 483, 492-93 n.9 (1987). An important point to note here is that it is not entirely clear that the Federal Arbitration Act will apply to charters and bylaws, since charters and bylaws are technically not "contracts" under the Act. Even in earlier cases, such as Boilermakers and ATP Tour, the Delaware courts did not hold that charters and bylaws are contracts. If charters and bylaws are construed as contracts, then even if a corporation were to adopt a mandatory arbitration provision in its organizational document, such a clause will be honored under the Federal Arbitration Act. See Ann Lipton, Manufactured Consent: The Problem of Arbitration Clauses in Corporate Charters and Bylaws, 104 Geo L.J. 583 (2016).

${ }^{129}$ See, e.g., Fisch, infra note 136, at 377 ("courts should engage in greater scrutiny of board-adopted bylaws because shareholders may be unable to remove those bylaws themselves"); Hershkoff \& Kahan, infra note 136 (arguing that forum selection clauses that lack any shareholder consent, or even meaningful consent, should not be enforced). If the directors were to adopt a mandatory arbitration provision without specific approval from the shareholders, the claim of unconscionability or even "bad faith" modification of bylaws becomes stronger. See, e.g., Choi \& Min, supra note 4(discussing how unilateral adoption of bylaw 
relinquishing the right to sue altogether cannot be effected without express consent. Thus, the validity of mandatory arbitration provisions requires a separate analysis, and does not immediately follow from validating FFPs.

\section{B. The Boundaries of Internal Affairs}

The second issue is whether a 1933 Act claim can be treated as an "internal" corporate claim. Under DGCL §115, "internal corporate claims" are claims "that are based upon a violation of a duty by a current or former director or officer or stockholder in such capacity. . ."130 While the statutory provision offers a useful starting point in thinking about the boundaries of "internal corporate claims," it presumably does not override the existing case-law-based doctrine. As mentioned earlier, Boilermakers makes an important distinction between "internal" and "external" claims. However, the distinction made in Boilermakers was not so exact so as to exclude any claim under federal law. The main distinction relied on in Boilermakers was between the rights of stockholders, which are governed by the charter and bylaws, and the rights of third parties, which are not. As stated in Boilermakers:

the bylaws would be regulating external matters if the board adopted a bylaw that purported to bind a plaintiff, even a stockholder plaintiff, who sought to bring a tort claim against the company based on a personal injury she suffered that occurred on the company's premises or a contract claim based on a commercial contract with the corporation. ${ }^{131}$

The decision in Sciabacucchi applies this analysis to claims under the 1933 Act by stating:

For purposes of the analysis in Boilermakers, a 1933 Act claim resembles a tort or contract claim brought by a third-party plaintiff who was not a stockholder at the time the claim arose. At best for the defendants, a 1933 Act claim resembles a tort or contract claim brought by a plaintiff who happens also to be a stockholder, but

provisions can run afoul of the contract law requirement of good faith modification). We acknowledge however that in practice, federal courts tend to affirm arbitration provisions, and only rarely hold them to be unconscionable. See Diane P. Wood, The Brave New World of Arbitration, 31 CAP. U. L. Rev. 383 (2003).

${ }^{130}$ One expansive notion of an "internal corporate claim" is to argue that, for instance, when directors or officers make material misrepresentation or material omission in the IPO documents and this allows stockholders to bring a 1933 Act claim, that claim is "based upon" the directors' or officers' violation of duty. See Grundfest, supra note 39, at 56-62 (arguing that because, among others, Section 11 claims "always implicate the care with which directors reviewed the allegedly defective registration statement," they are "internal" claims).

${ }^{131}$ See Boilermakers, 73 A.3d at 952. 
under circumstances where stockholder status is incidental to the claim. ${ }^{132}$

That is, according to the court, a stockholder acts in two capacities: first, as a purchaser with respect to the initial purchase of its shares, and second, as a stockholder after that purchase. ${ }^{133}$ A claim under the 1933 Act relates to the first capacity only.

However, is a 1933 Act claim similar to a claim in tort or a claim in contract? It is true that at the time an investor purchases a share, the investor is not yet a stockowner. However, when the purchased security is a share, the right to sue under the 1933 Act relates directly to the investor's status as a stockholder. ${ }^{134}$ The claimant would not be able to sue at all if they did not become a shareholder, and the lawsuit will likely have a direct effect on the relationship between shareholders and the corporation. ${ }^{135}$ Consistent with this reasoning, a more flexible version of the internal affairs doctrine would govern the claims that are raised by shareholders (qua shareholders) against the corporation, regardless of whether the claim is based on federal or state law, so long as they deal with the "internal" relationship between the shareholders and the corporation. This is buttressed by the fact that the investors who buy shares in the corporation buy these shares subject to the terms specified in the charter and bylaws of the corporation, which are (as explained in Boilermakers) part of the corporate "contract" between the corporation and stockholders that regulates the "internal" relationship between the shareholders and the corporation. ${ }^{136}$ By contrast, a consumer that buys a product

${ }^{132}$ Sciabacucchi v. Salzberg, 2018 WL 6719718, at *38 (Del. Ch. 2018).

${ }^{133}$ See James J. Park, Reassessing the Distinction Between Corporate and Securities Law, 64 UCLA L. REv. 116 (2017) (asserting that federal securities law governs the purchase of stocks by investors, while state corporate law dictates the rights of shareholders as owners of the corporation).

${ }^{134}$ See, e.g., Alison Frankel, Does Delaware Law Preclude Mandatory Arbitration of Federal Securities Claims?, Reuters (Nov. 26, 2018, 3:47 PM), https://www.reuters.com/article/ us-otc-shareholderarb/does-delaware-law-preclude-mandatory-arbitration-of-federal-securities-claims-idUSKCN1NV2JT (quoting Professor Pritchard as saying that "he disagrees with the ... argument that federal securities fraud claims do not arise from shareholders' charter and bylaw agreements.").

${ }^{135}$ Hypothetically, if the 1933 Act did not exist, an investor who alleged misstatement in an IPO document could presumably only raise a common law fraud claim, rather than a corporate law claim. Nonetheless, a charter or bylaw provision that regulates this claim would be valid, because the claimant is a shareholder, and the claim relates closely to the rights of shareholders.

${ }^{136}$ See Boilermakers, 73 A.3d at 940. Shareholders are deemed to have inspected the charter and bylaws as to matters governed by the DGCL, even without contemporaneously assenting to them when buying shares. See, e.g., Joseph A. Grundfest \& Kristen A. Savelle, The Brouhaha Over Intra-Corporate Forum Selection Provisions: A Legal, Economic, and Political Analysis, 68 Bus. Law. 325 (2013). Several scholars have contested the extension of the contract paradigm to the analysis of corporate charters and bylaws. See, e.g., James D. Cox, Corporate Law and the Limits of Private Ordering, 93 WASH. U. L. Rev. 257 (2015); Jill E. Fisch, Governance by Contract: The Implications for Corporate Bylaws, 106 CALIF. L. Rev. 372 (2018); Helen Hershkoff \& Marcel Kahan, Forum-Selection Provisions in Corporate “Contracts”, 93 WASH. L. Rev. 265 (2018). 
from a corporation or a tort victim of the corporation presumably is not bound by any of the provisions of the charter or bylaws, ${ }^{137}$ and thus, such claims are truly "external" to the corporation.

Prior decisions from Delaware's corporate jurisprudence provide support for this flexible interpretation of the internal affairs doctrine. In VantagePoint Venture Partners 1996 v. Examen, Inc. ${ }^{138}$ the Delaware Supreme Court held that the internal affairs doctrine "applies to those matters that pertain to the relationships among or in between the corporation and its officers, directors, and shareholders." 139 The court saw the internal affairs as "not . . . only a conflicts of law principle." 140 The court explained that the doctrine also served a valuable role by prospectively informing directors and officers about the law that will apply to their actions, and informing shareholders about the standards to which they can hold corporate executives. ${ }^{141}$ FFPs similarly regulate the relationship between two parties "internal" to the corporation: the managers (directors and officers) making disclosure decisions, and the shareholders deciding where to bring a lawsuit based on the disclosure. The FFPs put both managers and shareholders on notice that a 1933 Act violation will be litigated in a federal district court.

The flexible internal affairs notion is also buttressed by the existing regulatory framework which already allows overlapping jurisdiction. We have noted earlier how Delaware corporate law regulates stockholders' right to purchase and sell securities and other non-corporate claimants' rights in liquidation proceedings. Another important area is with respect to proxy. The SEC's Rule 14a-8 (under the 1934 Act) allows companies to exclude shareholder proposals from their proxy materials if the proposals seek to influence the outcomes of director elections. ${ }^{142}$ Under federal law, therefore, companies can force shareholders wishing to nominate directors to circulate their own dissident proxy with their slate of candidates. However, in 2009, Delaware enacted $\$ 112$ of the DGCL to permit (but not mandate) corporations to adopt bylaws that allow shareholders to access companies' proxies when nominating their own director candidates. ${ }^{143}$ These bylaws, if adopted, would seem to modify the company's ability exclude shareholders' nominees from the proxy statement, ${ }^{144}$ and some practitioners believe that $\$ 112$ "would appear to preclude an argument" that shareholders' attempts to influ-

${ }^{137}$ See Vincent S.J. Buccola, Opportunism and Internal Affairs, 93 Tulane L. Rev. 339, 370 (2018) (explaining that tort victims and consumers are "external" to the corporation since they are unlikely to opportunistically move to another jurisdiction with more lenient product liability or tort laws).

${ }_{138} 871$ A.2d 1108 (Del. 2005).

${ }^{139} \mathrm{Id}$. at 1113 .

${ }^{140} \mathrm{Id}$.

${ }^{141}$ See id.

${ }_{142}^{14}$ See 17 C.F.R. $\S 240.14 a-8(i)(8)$ (2018).

${ }^{143}$ See Del. Code AnN., tit. 8, § 112 (2018).

${ }^{144}$ When the SEC tried unsuccessfully to make similar shareholder access to proxy materials mandatory in 2010, it acknowledged that Section 112 "enable[d] companies to provide in their governing documents an ability for shareholders to include their director nominees in the 
ence director elections are excludable under Rule 14a-8. ${ }^{145}$ That is, Delaware's corporate law seems to facilitate bylaw provisions that modify the rights of the company under federal law. Extending this framework to the 1933 Act, Delaware courts can conceivably allow bylaw or charter provisions that modify shareholders' federal rights in bringing 1933 Act claims.

We also note that while it is true that the 1933 Act applies to any security - such as publicly-traded debt securities_and therefore the potential claimants may be bondholders, ${ }^{146}$ there is no compelling reason to invalidate FFPs as they apply to shareholders. Foremost, given that DGCL $\S \S 102(b)$ and 109(b) mention only the rights of the "stockholders," dictating the forum for other types of investors, such as debt-holders, through a charter or bylaws would be inconsistent with the statutory command. ${ }^{147}$ Furthermore, Boilermakers explicitly rejected the view that validating a provision implies that it has broad applicability irrespective of the circumstances, and explicitly advocated "judicial reticence to chill corporate freedom by condemning as invalid a bylaw that is consistent with the board's statutory and contractual authority, simply because it might be possible to imagine situations when the bylaw might operate unreasonably." 148 Consistent with this approach, even under the more "flexible" conception of internal affairs, it seems quite persuasive for courts to find that FFPs to apply to shareholders only. ${ }^{149}$

company's proxy materials," and that such statutes proved that "private ordering is an alternative to our new rules." 75 Fed. Reg. 56,668, 56,774-75 (Sept. 6, 2010).

${ }^{145}$ Robert K. Morris, Reacting to Shareholder Proxy Access Proposals, Harv. L. ScH. F. on Corp. Governance \& Fin. Reg. (Nov. 5, 2011), https://corpgov.law.harvard.edu/2011/11/ 05/reacting-to-shareholder-proxy-access-proposals/.

${ }^{146}$ See 15 U.S.C. § 77b (2018) (defining a "security" in expansive terms); see also Reves v. Ernst \& Young, 494 U.S. 56, 67 (1990) (stating that [a] note is presumed to be a "security"); Sciabacucchi, 2018 WL 6719718, at *17 ("Shares are just one of . . many types of securities.").

${ }^{147}$ There is some statutory ambiguity under DGCL $\$ 115$, however. The section defines "internal corporate claims" to mean "claims. . that are based upon a violation of a duty by a current or former director or officer or stockholder in such capacity. . ." With respect to debtholders, one could plausibly argue that the directors and officers (and possibly also the stockholders) have a contractual "duty" (as opposed to fiduciary duty) to them and, hence, when debt-holders bring a breach of contract (indenture or credit agreement) claim against them, this can qualify as an "internal corporate claim."

${ }_{148}$ Boilermakers, 73 A.3d at 949 n.62.

${ }^{149}$ This approach is consistent with a broader understanding of the internal affairs doctrine as being closely intertwined with the shareholder primacy norm that characterizes American corporate law. See Jill E. Fisch \& Steven Davidoff Solomon, Centros, California's "Women on Boards" Statute and the Scope of Regulatory Competition, Eur. Bus. L. REv. (forthcoming) (manuscript at 10). The paradigm is based on the idea that firms, through their managers, will choose the laws and provisions that maximize the value of these firms because efficient markets will price these governance structures, and managers have the legal duty to maximize firm value. See Roberta Romano, The Genius of American Corporate Law (1993). Thus, rules designed to address issues of general social welfare and the rights of stakeholders fall outside the internal affairs doctrine. On the other hand, rules that facilitate shareholder wealth may be viewed as related to the internal affairs of the corporation. See Fisch \& Davidoff, "Women on Boards," at 11. To the extent that it suggests that FFPs enhance shareholder value, the empirical analysis is consistent with the internal affairs doctrine permitting such provisions. 
We acknowledge that the internal affairs doctrine is constrained by federal laws that preempt state laws. ${ }^{150}$ At the same time, however, validating FFPs in charters and bylaws is consistent with federal courts' broad deference to "contractual" provisions that regulate the resolution of legal disputes. In Bremen v. Zapata Off-Shore Co., ${ }^{151}$ the Supreme Court held that forum selection clauses in commercial agreements are valid, provided that they are "unaffected by fraud, undue influence, or overweening bargaining power," 152 and that the provisions "should be enforced unless enforcement is shown by the resisting party to be unreasonable." 153 There is little reason to believe that restricting claims under the 1933 Act to federal courts would be wrongful under the Bremen test. While charters and bylaws are technically not "contracts," when validating exclusive forum bylaws with respect to breach of fiduciary duty claims, the Boilermakers court heavily relied on the Supreme Court's reasoning in Bremen. ${ }^{154}$ Furthermore, the Supreme Court has taken a deferential approach to forum selection, even in the context of the 1933 Act. In Rodriguez de Quijas v. Shearson/American Express, Inc., ${ }^{155}$ the Court held that brokerage firms can, through a mandatory arbitration clause in a customer agreement, compel investors to arbitrate 1933 Act claims under the Federal Arbitration Act. The Rodriguez opinion further stated that "the right to select the judicial forum and the wider choice of courts are not . . . essential features of [the 1933 Act]." ${ }^{156}$ Unlike arbitration

${ }^{150}$ There is dictum in Sciabacucchi that suggests that FFPs are preempted by federal law. See Sciabacucchi v. Salzberg, 2018 WL 6719718, at*23 (Del. Ch. 2018) ("[B]ecause the Federal Forum Provisions conflict with the forum alternatives that the 1933 Act permits, the provisions could be preempted."). However, Delaware courts have interpreted Supreme Court precedent to conclude that applications of the internal affairs doctrine are not preempted by federal law so long as Delaware is simply regulating the affairs of corporations incorporated in the state. See McDermott Inc. v. Lewis, 531 A.2d 206, 217 n.12 (Del. 1987) (stating "a state does not violate the commerce clause, notwithstanding heavy burdens imposed upon interstate commerce, if a state is merely regulating the internal affairs of its own corporations") (citing CTS Corp. v. Dynamics Corp. of America, 481 U.S. 69 (1987)) (emphasis added). Therefore, even if the companies using FFPs are headquartered in California and other states, so long as they are incorporated in Delaware, the flexible approach to the internal affairs doctrine suggests that Delaware corporate law can regulate these clauses.

151407 U.S. 1 (1972).

${ }^{152} \mathrm{Id}$. at 12 .

${ }^{153}$ Id. at 10. The Delaware Supreme Court has also closely conformed to the Bremen decision, holding that "where contracting parties have expressly agreed upon a legally enforceable forum selection clause, a court should honor the parties' contract and enforce the clause." Ingres Corp. v. CA, Inc., 8 A.3d 1143, 1145 (Del. 2010).

${ }^{154}$ See Boilermakers, 73 A.3d at 957-58.

155490 U.S. 477 (1989).

${ }^{156} I d$. at 481 . Specifically, the court held that an arbitration agreement does not contravene Section 14 of the 1933 Act, which forbids any agreements "to waive compliance with any provision" of the Act (15 U.S.C. $\$ 77 n$ (2018)). The Supreme Court has taken an equally deferential approach with respect to agreements to arbitrate claims individually in other contexts, such as claims for breach of consumer contracts, AT\&T Mobility LLC v. Concepcion, 563 U.S. 333 (2011), and even violating anti-trust laws, American Express Co. v. Italian Colors Rest., 570 U.S. 228 (2013). Note that in considering arbitration agreements, the court applies the Federal Arbitration Act of 1925, Pub. L. No. 68-401, 43 Stat. 883 (1925) (codified as amended in 9 U.S.C.), which established a "liberal federal policy favoring arbitration agree- 
agreements, FFPs do not deny claimants the right to sue in court, and thus as long as the adoption of an FFP is not the result of fraud or overweening bargaining power, it is likely to be viewed favorably by federal courts. Furthermore, at least under the Delaware jurisprudence, charters and bylaws are not formally considered as "contracts," thereby putting them potentially out of the reach of the Federal Arbitration Act. ${ }^{157}$

Before we conclude, one implication of adopting a more flexible conception of "internal affairs" is that FFPs that are contained in charters and bylaws will now be subject to DGCL $\S 115$, which states, in relevant part: "[t]he certificate of incorporation or the bylaws may require . . that any or all internal corporate claims shall be brought solely and exclusively in any or all of the courts in this State, and no provision of the certificate of incorporation or the bylaws may prohibit bringing such claims in the courts of this State." While it is not entirely clear what the phrase "the courts of this State" means, one can make a fairly persuasive argument that the phrase likely includes both the federal and state courts of Delaware. ${ }^{158}$ If an FFP were to dictate a federal forum that resides outside of Delaware, for instance, one can argue that such an FFP would be inconsistent with the statute. A more consistent approach, on the other hand, would allow a plaintiff to bring (or at least not prohibit a plaintiff from bringing) a 1933 Act claim in a Delaware federal district court. ${ }^{159}$ Furthermore, unlike the previous, more expansive construction of DGCL §102(b), under the more flexible internal affairs doctrine, a forum provision for 1933 Act claims that dictates any nonDelaware (either federal or state) forum, including mandatory arbitration provisions, would be invalid. A fee-shifting provision also will not be allowed under DGCL $\S \S 102$ (f) and 109(b). To the extent that the Delaware legislature deemed disallowing non-Delaware forum or fee-shifting provisions important, the flexible internal affairs approach may be more consistent with that legislative intent.

\section{CONCLusion}

Federal forum provisions constitute a unique legal device at the intersection of corporate and federal securities laws. These provisions have attracted criticism from both academics and practitioners, in large part because

ments, notwithstanding any state substantive or procedural policies to the contrary." Moses H. Cone Mem'l Hosp. v. Mercury Constr. Corp., 460 U.S. 1, 24 (1983).

${ }^{157}$ See supra note 128 for a more detailed discussion.

${ }^{158}$ See Grundfest, supra note 39, at 70-72 (parsing the statutory language of DGCL $\$ 115$ and arguing that "in the courts of this State" includes federal district court in Delaware).

${ }^{159}$ In Sciabacucchi, the defendant companies, Roku, Stitch Fix, and Blue Apron, adopted charter provisions which stated, in relevant part: "the federal district courts of the United States of America shall be the exclusive forum for the resolution of any complaint asserting a cause of action arising under the Securities Act of 1933." See Sciabacucchi at 13-14. Since such charter (or bylaw) provision does not "prohibit" plaintiffs from bringing a 1933 Act claim in the Delaware federal district court, assuming that the phrase "the courts of this State" includes the Delaware federal district court, the provision will be consistent with DGCL $\$ 115$. 
they constitute a private ordering device that customizes (and restricts) rights conferred on shareholders by Congress and interpreted by the Supreme Court in Cyan. On the other side of the spectrum, proponents of federal forum provisions have argued that they may serve a useful role in curbing excessive litigation and may direct litigation to its most natural forum, federal courts, where the cases will be subject to the various procedural and substantive rules under the PSLRA and SLUSA that Congress thought desirable for federal securities litigation.

The Article has attempted to shed some light on this issue through empirical analysis. Our findings, while not conclusive, are consistent with the more benign and positive view of FFPs. The analysis has shown that the firms that adopt them tend to be firms that are often the target of shareholder lawsuits, but they do not appear to be the firms that are susceptible to high agency costs. Moreover, the Sciabacucchi decision that validated these provisions is associated with a large negative stock price effect on the firms that had previously adopted FFPs. This analysis thus suggests that there may be good policy-based reasons to support the Delaware Supreme Court's reversal of Sciabacucchi, or for Congress to create exclusive federal jurisdiction for 1933 Act claims.

Finally, we argue that validating FFPs does not necessarily interfere with the existing corporate law doctrines (especially the internal affairs doctrine) and Delaware corporate law, and also is broadly consistent with the approach that federal courts have taken with respect to forum selection clauses. The question of whether to allow FFPs in corporate charters and bylaws raises two important issues in corporate law: to what extent we can treat charters and bylaws as a "contract" between corporations and shareholders, and the boundaries of the internal affairs doctrine. We have suggested two alternative approaches to allowing FFPs in charters and bylaws: either by expanding the set of subject matters that can be dealt with in charters and bylaws (the approach taken by the Delaware Supreme Court in Salzberg v. Sciabacucchi), or adopting a more "flexible" conception of the internal affairs doctrine. We have suggested how the latter approach can potentially better serve shareholders' interests and may be better in line with the broader framework of U.S. corporate law. 
Appendix A: Figures

Figure 1: Federal Exclusive Forum Provisions at IPO

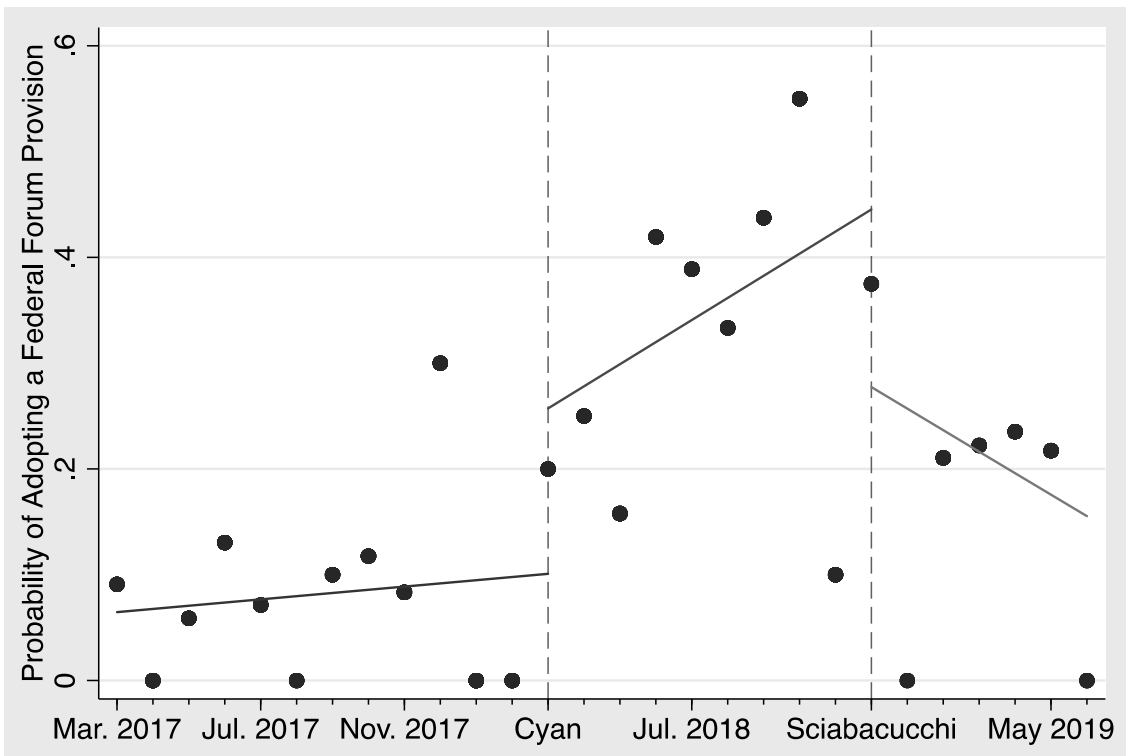

Figure 2: Stock Returns Around the Sciabacucchi Decision

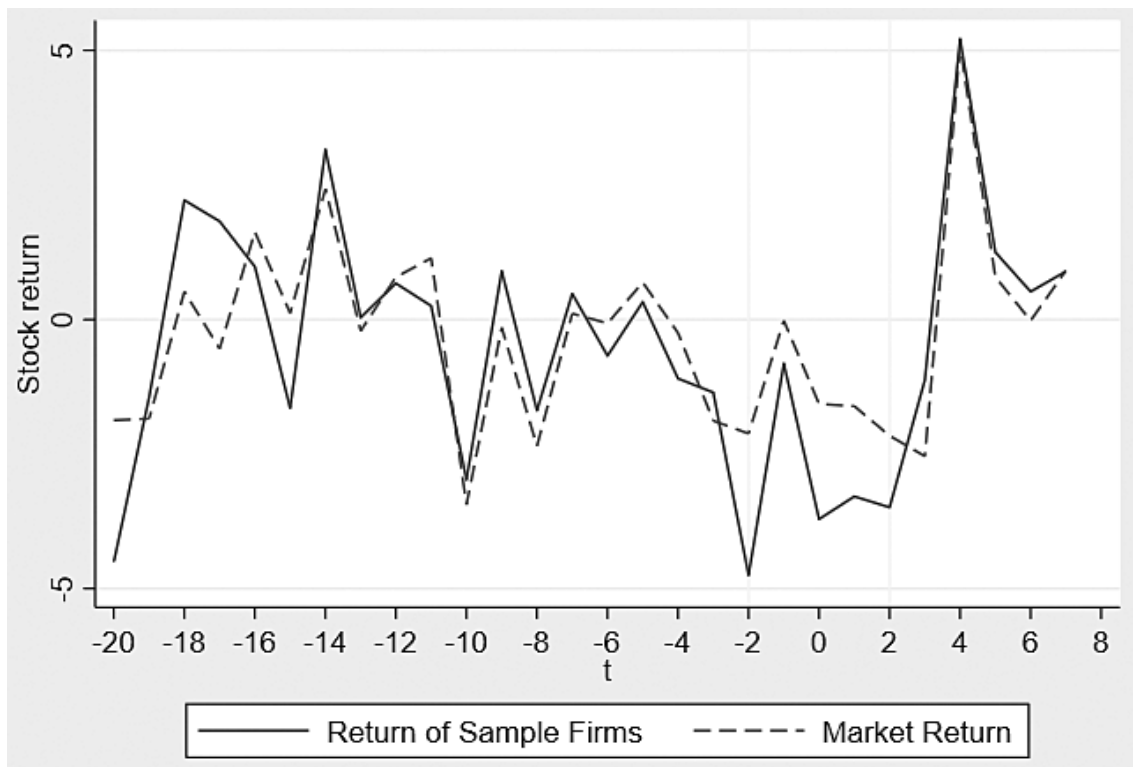


Figure 3: Abnormal Returns Around the Sciabacucchi Decision

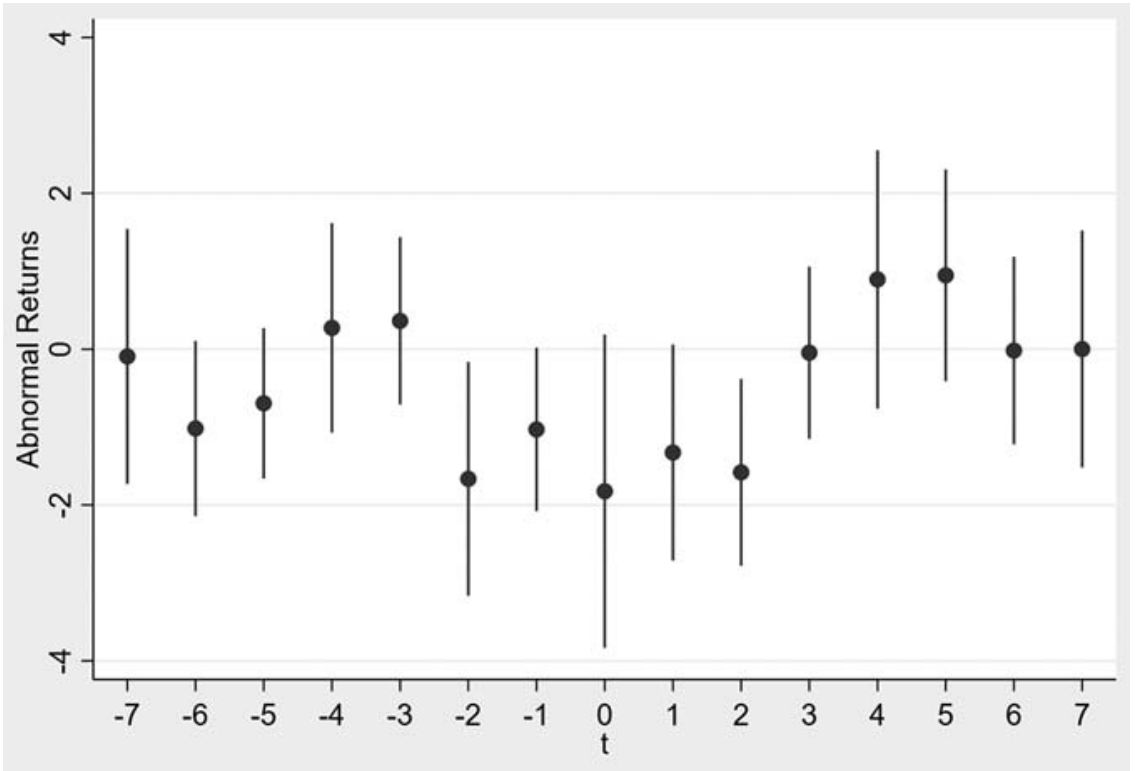




\section{Appendix B: TABLES}

\section{Table 1: Descriptive Statistics of Firms that Filed \\ a Registration Statement - 2017-2019}

\begin{tabular}{|l|c|c|c|c|c|c|c|c|c|}
\hline \hline & \multicolumn{4}{|c|}{ Adopting Firms } & \multicolumn{3}{|c|}{ Non-Adopting Firms } & \\
\cline { 2 - 10 } & $(\mathbf{1})$ & $(\mathbf{2})$ & $\mathbf{( 3 )}$ & $\mathbf{( 4 )}$ & $\mathbf{( 5 )}$ & $\mathbf{( 6 )}$ & $\mathbf{( 7 )}$ & $\mathbf{( 8 )}$ & $\mathbf{( 9 )}$ \\
\hline & Mean & Median & $\begin{array}{c}\text { Std. } \\
\text { Dev. }\end{array}$ & Obs. & Mean & Median & $\begin{array}{c}\text { Std. } \\
\text { Dev. }\end{array}$ & $\begin{array}{c}\text { Obs. } \\
\text { t-stats } \\
(\mathbf{1}) \text {-(5) }\end{array}$ \\
\hline IPO Under-pricing & 0.232 & 0.18 & 0.268 & 70 & 0.106 & 0.017 & 0.309 & 357 & 3.214 \\
Vulnerable Ind. & 0.747 & 1 & 0.437 & 91 & 0.408 & 0 & 0.492 & 532 & 6.177 \\
IPO Proceeds & 330.626 & 126.7 & 937.714 & 90 & 207.365 & 105 & 321.495 & 501 & 2.292 \\
Post-Cyan Pre-Sciabacucchi i & 0.637 & 1 & 0.483 & 91 & 0.329 & 0 & 0.47 & 532 & 5.758 \\
Post- Sciabacucchi & 0.176 & 0 & 0.383 & 91 & 0.199 & 0 & 0.4 & 532 & -0.520 \\
Negative Earning & 0.857 & 1 & 0.352 & 91 & 0.545 & 1 & 0.498 & 532 & 5.731 \\
Cash Ratio & 0.43 & 0.341 & 0.328 & 89 & 0.254 & 0.11 & 0.302 & 511 & 5.029 \\
VC/PE-Backed IPO & 0.813 & 1 & 0.392 & 91 & 0.32 & 0 & 0.467 & 532 & 9.529 \\
Dual-Class Stock & 0.198 & 0 & 0.401 & 91 & 0.31 & 0 & 0.463 & 532 & -2.179 \\
Delaware Inc. & 0.956 & 1 & 0.206 & 91 & 0.528 & 1 & 0.5 & 532 & 8.047 \\
California Hdq. & 0.516 & 1 & 0.502 & 91 & 0.148 & 0 & 0.356 & 532 & 8.521 \\
Law Firm & 0.626 & 1 & 0.486 & 91 & 0.094 & 0 & 0.292 & 532 & 14.33 \\
Age & 10.625 & 9 & 10.549 & 80 & 13.626 & 7 & 22.076 & 356 & -1.185 \\
\hline \hline All variables are defined in Appendix C. Financial variables are recorded for the fiscal year prior to the IPO. \\
\hline
\end{tabular}

Table 2: Descriptive Statistics of IPO Firms 1996-2018

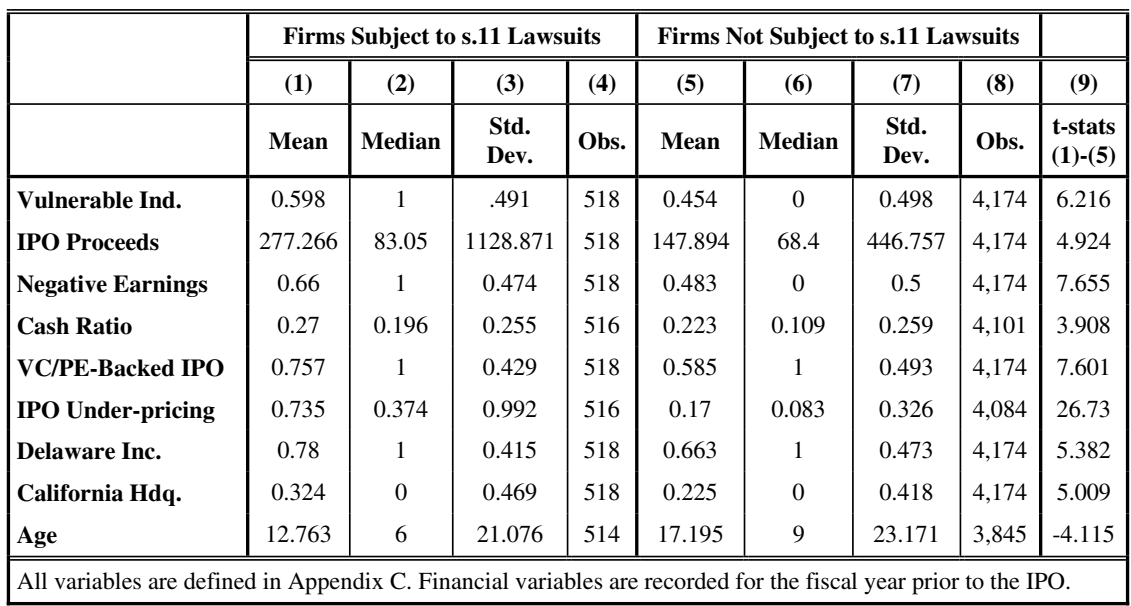


Table 3: Probability of Section 11 Lawsuits

\begin{tabular}{|c|c|c|c|c|c|}
\hline & (1) & (2) & (3) & (4) & (5) \\
\hline Vulnerable Ind. & $\begin{array}{c}0.512 * * * \\
(4.79)\end{array}$ & $\begin{array}{c}0.407 * * * \\
(3.55)\end{array}$ & $\begin{array}{l}0.188 \\
(1.55)\end{array}$ & $\begin{array}{l}0.184 \\
(1.52)\end{array}$ & $\begin{array}{l}0.142 \\
(1.17)\end{array}$ \\
\hline - Marginal effect & $\begin{array}{c}0.0443 * * * \\
(4.84)\end{array}$ & $\begin{array}{c}0.0355 * * * \\
\quad(3.56)\end{array}$ & $\begin{array}{c}0.0152 \\
(1.55)\end{array}$ & $\begin{array}{l}0.0150 \\
(1.52)\end{array}$ & $\begin{array}{c}0.0120 \\
(1.17)\end{array}$ \\
\hline $\begin{array}{l}\text { Log (IPO } \\
\text { Proceeds) }\end{array}$ & $\begin{array}{c}0.396 * * * \\
(8.32)\end{array}$ & $\begin{array}{c}0.426 * * * \\
(8.56)\end{array}$ & $\begin{array}{c}0.374 * * * \\
(6.88)\end{array}$ & $\begin{array}{c}0.375 * * * \\
(6.86)\end{array}$ & $\begin{array}{c}0.445 * * * \\
(7.63)\end{array}$ \\
\hline - Marginal effect & $\begin{array}{c}0.0343 * * * \\
(8.38)\end{array}$ & $\begin{array}{l}0.0371 * * * \\
(8.68)\end{array}$ & $\begin{array}{c}0.0304 * * * \\
(6.89)\end{array}$ & $\begin{array}{c}0.0304 * * * \\
(6.88)\end{array}$ & $\begin{array}{l}0.0376 * * * \\
\quad(7.67)\end{array}$ \\
\hline $\begin{array}{l}\text { Negative } \\
\text { Earnings }\end{array}$ & & $\begin{array}{c}0.338 * * * \\
(2.91)\end{array}$ & $\begin{array}{l}0.203^{*} \\
(1.65)\end{array}$ & $\begin{array}{l}0.190 \\
(1.52)\end{array}$ & $\begin{array}{l}0.186 \\
(1.46)\end{array}$ \\
\hline - Marginal effect & & $\begin{array}{l}0.0295 * * * \\
\quad(2.91)\end{array}$ & $\begin{array}{c}0.0165^{*} \\
(1.65)\end{array}$ & $\begin{array}{l}0.0154 \\
(1.52)\end{array}$ & $\begin{array}{c}0.0158 \\
(1.46)\end{array}$ \\
\hline Cash Ratio & & $\begin{array}{l}0.218 \\
(1.08)\end{array}$ & $\begin{array}{l}-0.266 \\
(-1.18)\end{array}$ & $\begin{array}{l}-0.274 \\
(-1.21)\end{array}$ & $\begin{array}{l}-0.310 \\
(-1.35)\end{array}$ \\
\hline - Marginal effect & & $\begin{array}{c}0.0190 \\
(1.08)\end{array}$ & $\begin{array}{l}-0.0216 \\
(-1.17)\end{array}$ & $\begin{array}{c}-0.0222 \\
(-1.21)\end{array}$ & $\begin{array}{c}-0.0262 \\
(-1.34)\end{array}$ \\
\hline $\begin{array}{l}\text { VC/PE-Backed } \\
\text { IPO }\end{array}$ & & & $\begin{array}{c}0.352 * * * \\
(2.63)\end{array}$ & $\begin{array}{c}0.326 * * \\
(2.39)\end{array}$ & $\begin{array}{l}0.187 \\
(1.38)\end{array}$ \\
\hline - Marginal effect & & & $\begin{array}{l}0.0286 * * * \\
\quad(2.63)\end{array}$ & $\begin{array}{c}0.0264 * * \\
(2.39)\end{array}$ & $\begin{array}{c}0.0158 \\
(1.38)\end{array}$ \\
\hline $\begin{array}{l}\text { IPO Under- } \\
\text { pricing }\end{array}$ & & & $\begin{array}{c}1.097 * * * \\
(9.81)\end{array}$ & $\begin{array}{c}1.089 * * * \\
(9.72)\end{array}$ & $\begin{array}{c}1.091 * * * \\
(9.94)\end{array}$ \\
\hline - Marginal effect & & & $\begin{array}{c}0.0891 * * * \\
(10.34)\end{array}$ & $\begin{array}{c}0.0884 * * * \\
(10.23)\end{array}$ & $\begin{array}{c}0.0922 * * * \\
(10.46)\end{array}$ \\
\hline Delaware Inc. & & & & $\begin{array}{c}0.0972 \\
(0.75)\end{array}$ & $\begin{array}{c}0.00148 \\
(0.01)\end{array}$ \\
\hline - Marginal effect & & & & $\begin{array}{c}0.00789 \\
(0.75)\end{array}$ & $\begin{array}{c}0.000125 \\
(0.01)\end{array}$ \\
\hline California Hdq. & & & & $\begin{array}{c}0.0574 \\
(0.48)\end{array}$ & $\begin{array}{l}0.0435 \\
(0.36)\end{array}$ \\
\hline - Marginal effect & & & & $\begin{array}{c}0.00466 \\
(0.48)\end{array}$ & $\begin{array}{c}0.00368 \\
(0.36)\end{array}$ \\
\hline Age & & & & & $\begin{array}{c}-0.00735 * * \\
(-2.15)\end{array}$ \\
\hline - Marginal effect & & & & & $\begin{array}{c}-0.000621 * * \\
(-2.15)\end{array}$ \\
\hline $\begin{array}{l}\text { Pseudo R- } \\
\text { square }\end{array}$ & 0.140 & 0.142 & 0.193 & 0.193 & 0.193 \\
\hline Observations & 4,692 & 4,617 & 4,530 & 4,530 & 4,279 \\
\hline \multicolumn{6}{|c|}{$\begin{array}{l}\text { The dependent variable is an indicator equal to } 1 \text { if a firm is subject to a section } 11 \\
\text { lawsuit, and zero otherwise. } t \text { statistics in parentheses. } * \mathrm{p}<0.10, * * \mathrm{p}<0.05 \text {, } \\
* * * \mathrm{p}<0.01 \text {. All variables are defined in Appendix C. Financial variables are recorded } \\
\text { for the fiscal year prior to the IPO. }\end{array}$} \\
\hline
\end{tabular}


Table 4: Probability of Adopting an Exclusive Federal Forum Provision - 2017-2019

\begin{tabular}{|c|c|c|c|c|c|}
\hline & (1) & $(2)$ & (3) & (4) & $(5)$ \\
\hline Vulnerable Ind. & $\begin{array}{c}1.452 * * * \\
(5.24)\end{array}$ & $\begin{array}{c}0.811^{* * *} \\
(2.26)\end{array}$ & $\begin{array}{l}0.504 \\
(1.39)\end{array}$ & $\begin{array}{l}-0.153 \\
(-0.34)\end{array}$ & $\begin{array}{c}-0.0814 \\
(-0.15)\end{array}$ \\
\hline - Marginal effect & $\begin{array}{c}0.161^{* * *} \\
(5.47)\end{array}$ & $\begin{array}{c}0.0878 * * \\
(2.26)\end{array}$ & $\begin{array}{c}0.0504 \\
(1.39)\end{array}$ & $\begin{array}{c}-0.0110 \\
(-0.34)\end{array}$ & $\begin{array}{c}-0.00644 \\
(-0.15)\end{array}$ \\
\hline $\begin{array}{l}\text { Log (IPO } \\
\text { Proceeds) }\end{array}$ & $\begin{array}{c}0.370 * * * \\
(3.81)\end{array}$ & $\begin{array}{c}0.441 * * * \\
(4.36)\end{array}$ & $\begin{array}{c}0.394 * * * \\
(3.54)\end{array}$ & $\begin{array}{c}0.343 * * * \\
(2.65)\end{array}$ & $\begin{array}{l}0.297 * \\
(1.92)\end{array}$ \\
\hline - Marginal effect & $\begin{array}{c}0.0409 * * * \\
\quad(3.80)\end{array}$ & $\begin{array}{c}0.0477 * * * \\
\quad(4.37)\end{array}$ & $\begin{array}{c}0.0394 * * * \\
(3.51)\end{array}$ & $\begin{array}{c}0.0246 * * * \\
\quad(2.58)\end{array}$ & $\begin{array}{c}0.0235^{*} \\
(1.90)\end{array}$ \\
\hline $\begin{array}{l}\text { Post-Cyan Pre- } \\
\text { Sciabacucchi }\end{array}$ & $\begin{array}{c}1.483 * * * \\
(4.88)\end{array}$ & $\begin{array}{c}1.425 * * * \\
(4.54)\end{array}$ & $\begin{array}{c}1.586 * * * \\
(4.76)\end{array}$ & $\begin{array}{c}1.936 * * * \\
(5.05)\end{array}$ & $\begin{array}{c}2.024 * * * \\
(4.75)\end{array}$ \\
\hline - Marginal effect & $\begin{array}{c}0.164 * * * \\
(5.04)\end{array}$ & $\begin{array}{c}0.154 * * * \\
(4.87)\end{array}$ & $\begin{array}{c}0.159 * * * \\
(5.28)\end{array}$ & $\begin{array}{c}0.139 * * * \\
(5.89)\end{array}$ & $\begin{array}{c}0.160 * * * \\
(6.02)\end{array}$ \\
\hline $\begin{array}{l}\text { Post- } \\
\text { Sciabacucchi }\end{array}$ & $\begin{array}{l}0.696^{*} \\
(1.80)\end{array}$ & $\begin{array}{l}0.648 \\
(1.62)\end{array}$ & $\begin{array}{l}0.729^{*} \\
(1.75)\end{array}$ & $\begin{array}{l}0.286 \\
(0.54)\end{array}$ & $\begin{array}{l}0.561 \\
(0.85)\end{array}$ \\
\hline - Marginal effect & $\begin{array}{c}0.0771^{*} \\
(1.79)\end{array}$ & $\begin{array}{l}0.0702 \\
(1.62)\end{array}$ & $\begin{array}{c}0.0728^{*} \\
(1.77)\end{array}$ & $\begin{array}{l}0.0205 \\
(0.54)\end{array}$ & $\begin{array}{l}0.0444 \\
(0.86)\end{array}$ \\
\hline Negative Earning & & $\begin{array}{c}1.092 * * * \\
(2.76)\end{array}$ & $\begin{array}{l}0.659 \\
(1.56)\end{array}$ & $\begin{array}{l}0.220 \\
(0.43)\end{array}$ & $\begin{array}{l}0.281 \\
(0.44)\end{array}$ \\
\hline - Marginal effect & & $\begin{array}{c}0.118 * * * \\
(2.79)\end{array}$ & $\begin{array}{c}0.0659 \\
(1.57)\end{array}$ & $\begin{array}{c}0.0158 \\
(0.44)\end{array}$ & $\begin{array}{c}0.0222 \\
(0.44)\end{array}$ \\
\hline Cash Ratio & & $\begin{array}{c}0.962 * * \\
(2.23)\end{array}$ & $\begin{array}{l}0.452 \\
(0.98)\end{array}$ & $\begin{array}{l}0.181 \\
(0.34)\end{array}$ & $\begin{array}{l}0.247 \\
(0.43)\end{array}$ \\
\hline - Marginal effect & & $\begin{array}{c}0.104 * * \\
(2.26)\end{array}$ & $\begin{array}{l}0.0452 \\
(0.99)\end{array}$ & $\begin{array}{c}0.0130 \\
(0.34)\end{array}$ & $\begin{array}{l}0.0196 \\
(0.43)\end{array}$ \\
\hline $\begin{array}{l}\text { VC/PE-Backed } \\
\text { IPO }\end{array}$ & & & $\begin{array}{c}1.435 * * * \\
(4.26)\end{array}$ & $\begin{array}{c}0.943 * * \\
(2.47)\end{array}$ & $\begin{array}{c}0.910^{* *} \\
(1.98)\end{array}$ \\
\hline - Marginal effect & & & $\begin{array}{c}0.144 * * * \\
(4.39)\end{array}$ & $\begin{array}{c}0.0676^{* *} \\
(2.47)\end{array}$ & $\begin{array}{c}0.0720 * * \\
(1.99)\end{array}$ \\
\hline Dual-Class Stock & & & $\begin{array}{c}-0.867 * * \\
(-2.52)\end{array}$ & $\begin{array}{l}-0.531 \\
(-1.31)\end{array}$ & $\begin{array}{l}-0.470 \\
(-1.01)\end{array}$ \\
\hline - Marginal effect & & & $\begin{array}{c}-0.0867 * * \\
(-2.57)\end{array}$ & $\begin{array}{c}-0.0381 \\
(-1.27)\end{array}$ & $\begin{array}{c}-0.0372 \\
(-0.99)\end{array}$ \\
\hline Delaware Inc. & & & & $\begin{array}{c}2.545 * * * \\
(3.77)\end{array}$ & $\begin{array}{c}2.483 * * * \\
(3.19)\end{array}$ \\
\hline - Marginal effect & & & & $\begin{array}{c}0.182 * * * \\
(4.09)\end{array}$ & $\begin{array}{c}0.197 * * * \\
\quad(3.67)\end{array}$ \\
\hline California Hdq. & & & & $\begin{array}{c}1.145 * * * \\
(3.01)\end{array}$ & $\begin{array}{c}1.143 * * * \\
(2.68)\end{array}$ \\
\hline - Marginal effect & & & & $\begin{array}{c}0.0821 * * * \\
(3.04)\end{array}$ & $\begin{array}{c}0.0905 * * * \\
(2.68)\end{array}$ \\
\hline Law firm & & & & $\begin{array}{c}2.146 * * * \\
(5.85)\end{array}$ & $\begin{array}{c}2.292 * * * \\
(5.82)\end{array}$ \\
\hline
\end{tabular}




\begin{tabular}{l}
\hline \hline Marginal Effect \\
Age
\end{tabular}

Table 5: Probability of Adopting an Exclusive Federal Forum Provision And Litigation Probability - 2018-2019

\begin{tabular}{|c|c|c|c|}
\hline & (1) & (2) & (3) \\
\hline Litigation Probability & $\begin{array}{c}10.14 * * * \\
(3.56)\end{array}$ & $\begin{array}{c}13.76^{* * *} \\
(4.11)\end{array}$ & $\begin{array}{c}11.24 * * * \\
(3.05)\end{array}$ \\
\hline - Marginal effect & $\begin{array}{c}1.516^{* * * *} \\
(3.65)\end{array}$ & $\begin{array}{c}1.948 * * * \\
(4.30)\end{array}$ & $\begin{array}{c}1.201 * * * \\
(3.04)\end{array}$ \\
\hline Post-Cyan Pre- Sciabacucchi & $\begin{array}{c}2.339 * * * \\
(5.54)\end{array}$ & $\begin{array}{c}2.714 * * * \\
(5.45)\end{array}$ & $\begin{array}{c}2.499 * * * \\
(4.70)\end{array}$ \\
\hline - Marginal effect & $\begin{array}{c}0.350 * * * \\
(6.38)\end{array}$ & $\begin{array}{c}0.384 * * * \\
(6.63)\end{array}$ & $\begin{array}{c}0.267 * * * \\
(5.32)\end{array}$ \\
\hline Dual-Class Stock & & $\begin{array}{c}-1.320 * * * \\
(-3.15)\end{array}$ & $\begin{array}{c}-0.927 * * \\
(-2.10)\end{array}$ \\
\hline - Marginal effect & & $\begin{array}{c}-0.187 * * * \\
(-3.46)\end{array}$ & $\begin{array}{c}-0.0991 * * \\
(-2.10)\end{array}$ \\
\hline Law Firm & & & $\begin{array}{c}2.503 * * * \\
(6.43)\end{array}$ \\
\hline - Marginal effect & & & $\begin{array}{c}0.267 * * * \\
(9.64) \\
\end{array}$ \\
\hline Pseudo R-square & 0.123 & 0.166 & 0.326 \\
\hline Observations & 302 & 302 & 302 \\
\hline \multicolumn{4}{|c|}{$\begin{array}{l}\text { The dependent variable is an indicator equal to } 1 \text { if a firm adopted a federal } \\
\text { exclusive forum provision, and zero otherwise. } \mathrm{t} \text { statistics based on bootstrap } \\
\text { standard errors in parentheses. } * \mathrm{p}<0.10, * * \mathrm{p}<0.05 \text {, *** } \mathrm{p}<0.01 \text {. All } \\
\text { variables are defined in Appendix C. }\end{array}$} \\
\hline
\end{tabular}


Table 6: The Stock Price Effect of Sciabacucchi

\begin{tabular}{|c|c|c|c|c|c|c|}
\hline \hline $\mathbf{( 1 )}$ & $\mathbf{( 2 )}$ & $\mathbf{( 3 )}$ & $\mathbf{( 4 )}$ & $\mathbf{( 5 )}$ & $\mathbf{( 6 )}$ & $\mathbf{( 7 )}$ \\
\hline $\mathbf{A R}$ & $\mathbf{C A R}$ & $\mathbf{C A R}$ & $\mathbf{C A R}$ & $\mathbf{C A R}$ & $\mathbf{C A R}$ & $\mathbf{C A R}$ \\
$\mathbf{( 0 )}$ & $\mathbf{( 0 , + 1 )}$ & $\mathbf{( 0 , + 2 )}$ & $\mathbf{( - 1 , + 1 )}$ & $\mathbf{( - 2 , + 2 )}$ & $\mathbf{( - 7 , - 3 )}$ & $\mathbf{( + 3 , + 7 )}$ \\
\hline \hline$-1.823 *$ & $-3.150 * * *$ & $-4.731 * * *$ & $-4.181 * * *$ & $-7.426 * * *$ & -1.171 & 1.781 \\
$(-1.81)$ & $(-2.68)$ & $(-3.23)$ & $(-2.89)$ & $(-3.82)$ & $(-0.91)$ & $(1.15)$ \\
\hline
\end{tabular}

Table 7: The Stock Price Effect of Sciabacucchi using Portfolio Analysis

\begin{tabular}{|c|c|c|c|c|c|c|}
\hline & (1) & (2) & (3) & (4) & (5) & (6) \\
\hline & $\begin{array}{c}\text { Event } \\
\text { Window } \\
0\end{array}$ & $\begin{array}{c}\text { Event } \\
\text { Window } \\
(0,+1)\end{array}$ & $\begin{array}{c}\text { Event } \\
\text { Window } \\
(0,+2)\end{array}$ & $\begin{array}{c}\text { Event } \\
\text { Window } \\
(-1,+1)\end{array}$ & $\begin{array}{c}\text { Event } \\
\text { Window } \\
(-2,+2)\end{array}$ & $\begin{array}{c}\text { Event } \\
\text { Window } \\
(-2,+2)\end{array}$ \\
\hline $\begin{array}{l}\text { AR } \\
\operatorname{AR}(-3,-7) \\
\operatorname{AR}(+3,+7)\end{array}$ & $\begin{array}{c}-1.829 * * \\
(-2.41)\end{array}$ & $\begin{array}{c}-1.570 * * * \\
(-2.91)\end{array}$ & $\begin{array}{c}-1.572 * * * \\
(-3.46)\end{array}$ & $\begin{array}{c}-1.385 * * * \\
(-3.17)\end{array}$ & $\begin{array}{c}-1.468 * * * \\
(-4.21)\end{array}$ & \begin{tabular}{|c|}
$-1.451 * * *$ \\
$(-4.27)$ \\
-0.243 \\
$(-0.73)$ \\
0.333 \\
$(1.01)$ \\
\end{tabular} \\
\hline CAR & $\begin{array}{c}-1.829 * * \\
(-2.41)\end{array}$ & $\begin{array}{c}-3.14 * * * \\
(-4.12)\end{array}$ & $\begin{array}{c}-4.716^{* * * *} \\
(-5.99)\end{array}$ & $\begin{array}{c}-4.155^{* * *} \\
(-5.49)\end{array}$ & $\begin{array}{c}-7.34 * * * \\
(-9.41)\end{array}$ & $\begin{array}{c}-7.255^{* * * *} \\
(-9.55)\end{array}$ \\
\hline Observations & 121 & 122 & 123 & 123 & 125 & 135 \\
\hline
\end{tabular}


Table 8: The Stock Price Effect of Sciabacucchi by Firm Type

\begin{tabular}{|c|c|c|c|c|c|c|}
\hline (1) & (2) & (3) & (4) & (5) & (6) & (7) \\
\hline $\begin{array}{c}\mathbf{A R} \\
(\mathbf{0})\end{array}$ & $\begin{array}{c}\text { CAR } \\
(\mathbf{0},+1)\end{array}$ & $\begin{array}{c}\text { CAR } \\
(0,+2)\end{array}$ & $\begin{array}{c}\text { CAR } \\
(-1,+1)\end{array}$ & $\begin{array}{c}\text { CAR } \\
(-2,+2)\end{array}$ & $\begin{array}{c}\text { CAR } \\
(-7,-3)\end{array}$ & $\begin{array}{c}\text { CAR } \\
(+3,+7)\end{array}$ \\
\hline \multicolumn{7}{|c|}{ Panel A: Firms from Industries that are Prone to Litigation $(N=47)$} \\
\hline $\begin{array}{l}-2.412 * \\
(-2.00)\end{array}$ & $\begin{array}{c}-3.686 * * * \\
(-2.97)\end{array}$ & $\begin{array}{c}-5.255^{* * * *} \\
(-3.32)\end{array}$ & $\begin{array}{c}-4.877 * * * \\
(-3.06)\end{array}$ & $\begin{array}{c}-9.085 * * * \\
(-4.51)\end{array}$ & $\begin{array}{l}-0.811 \\
(-0.49)\end{array}$ & $\begin{array}{l}1.589 \\
(0.78)\end{array}$ \\
\hline \multicolumn{7}{|c|}{ Panel B: Federal Forum Provision in the Charter $(N=42)$} \\
\hline $\begin{array}{l}-1.371 \\
(-1.40)\end{array}$ & $\begin{array}{c}-2.381 * \\
(-1.84)\end{array}$ & $\begin{array}{c}-4.482 * * * \\
(-2.74)\end{array}$ & $\begin{array}{c}-2.897 * \\
(-1.74)\end{array}$ & $\begin{array}{c}-6.113 * * * \\
(-2.72)\end{array}$ & $\begin{array}{l}-2.732 \\
(-1.61)\end{array}$ & $\begin{array}{l}0.871 \\
(0.40)\end{array}$ \\
\hline \multicolumn{7}{|c|}{ Panel C: IPO Firms $(N=54)$} \\
\hline $\begin{array}{c}-2.652 * * \\
(-2.31)\end{array}$ & $\begin{array}{c}-3.947 * * * \\
(-2.94)\end{array}$ & $\begin{array}{c}-5.875 * * * \\
(-3.54)\end{array}$ & $\begin{array}{c}-4.870 * * * \\
(-2.93)\end{array}$ & $\begin{array}{c}-8.404 * * * \\
(-3.80)\end{array}$ & $\begin{array}{l}-2.262 \\
(-1.63)\end{array}$ & $\begin{array}{l}1.233 \\
(0.74)\end{array}$ \\
\hline \multicolumn{7}{|c|}{ Panel D: Excluding Firms with Dual-Class Stock post IPO $(\mathrm{N}=41)$} \\
\hline $\begin{array}{c}-2.999 * * \\
(-2.05)\end{array}$ & $\begin{array}{c}-4.555^{* *} \\
(-2.70)\end{array}$ & $\begin{array}{c}-6.009 * * * \\
(-2.89)\end{array}$ & $\begin{array}{c}-6.126 * * * \\
(-3.16)\end{array}$ & $\begin{array}{c}-8.528 * * * \\
(-3.14)\end{array}$ & $\begin{array}{l}-1.534 \\
(-1.12)\end{array}$ & $\begin{array}{l}0.506 \\
(0.30)\end{array}$ \\
\hline \multicolumn{7}{|c|}{ Panel E: Firms that Under-priced their Securities at the IPO $(N=46)$} \\
\hline $\begin{array}{c}-1.541 * \\
(-1.75)\end{array}$ & $\begin{array}{c}-2.874 * * \\
(-2.31)\end{array}$ & $\begin{array}{c}-5.243 * * * \\
(-3.28)\end{array}$ & $\begin{array}{c}-3.615^{* *} \\
(-2.20)\end{array}$ & $\begin{array}{c}-7.567 * * * \\
(-3.34)\end{array}$ & $\begin{array}{l}-2.797 * \\
(-1.97)\end{array}$ & $\begin{array}{l}2.012 \\
(1.19)\end{array}$ \\
\hline \multicolumn{7}{|c|}{$\begin{array}{l}\text { Panel F: Firms with a Share Price Higher than the IPO Price before Sciabacucchi } \\
(\mathrm{N}=28)\end{array}$} \\
\hline $\begin{array}{c}-2.384 * * \\
(-2.34)\end{array}$ & $\begin{array}{c}-2.968 * * \\
(-2.23)\end{array}$ & $\begin{array}{c}-5.256^{* * * *} \\
(-3.11)\end{array}$ & $\begin{array}{c}-3.133^{*} \\
(-1.72)\end{array}$ & $\begin{array}{c}-9.019 * * * \\
(-4.11)\end{array}$ & $\begin{array}{l}-1.907 \\
(-0.91)\end{array}$ & $\begin{array}{l}0.793 \\
(0.53)\end{array}$ \\
\hline
\end{tabular}


Table 9: The Stock Price Effect of Sciabacucchi using Portfolio Analysis by Firm Type

\begin{tabular}{|c|c|c|c|c|c|c|}
\hline \multicolumn{7}{|c|}{ Panel A: Firms from Industries that are Prone to Litigation $(N=47)$} \\
\hline & (1) & (2) & (3) & (4) & (5) & (6) \\
\hline & $\begin{array}{c}\text { Event } \\
\text { Window } \\
0\end{array}$ & $\begin{array}{c}\text { Event } \\
\text { Window } \\
(0,+1)\end{array}$ & $\begin{array}{c}\text { Event } \\
\text { Window } \\
(0,+2)\end{array}$ & $\begin{array}{c}\text { Event } \\
\text { Window } \\
(-1,+1)\end{array}$ & $\begin{array}{c}\text { Event } \\
\text { Window } \\
(-2,+2)\end{array}$ & $\begin{array}{c}\text { Event } \\
\text { Window } \\
(-2,+2)\end{array}$ \\
\hline $\mathrm{AR}$ & $\begin{array}{c}-2.405^{* *} \\
(-2.56)\end{array}$ & $\begin{array}{c}-1.823 * * * \\
(-2.74)\end{array}$ & $\begin{array}{c}-1.732 * * * \\
(-3.08)\end{array}$ & $\begin{array}{c}-1.600 * * * \\
(-2.96)\end{array}$ & $\begin{array}{c}-1.790 * * * \\
(-4.13)\end{array}$ & $\begin{array}{c}-1.753 * * * \\
(-4.15)\end{array}$ \\
\hline $\operatorname{AR}(-3,-7)$ & & & & & & $\begin{array}{l}-0.160 \\
(-0.39)\end{array}$ \\
\hline $\mathrm{AR}(+3,+7)$ & & & & & & $\begin{array}{l}0.304 \\
(0.74) \\
\end{array}$ \\
\hline CAR & $\begin{array}{c}2.405 * * \\
(-2.56) \\
\end{array}$ & \begin{tabular}{|c|}
$-3.646 * * *$ \\
$(-3.875)$ \\
\end{tabular} & \begin{tabular}{|c}
$-5.196 * * *$ \\
$(-5.335)$ \\
\end{tabular} & $\begin{array}{c}-4.800 * * * \\
(-5.127)\end{array}$ & $\begin{array}{c}-8.950 * * * \\
(-9.235)\end{array}$ & $\begin{array}{c}-8.765 * * * \\
(-9.280)\end{array}$ \\
\hline \multicolumn{7}{|c|}{ Panel B: Federal Forum Provision in the Charter $(\mathrm{N}=42)$} \\
\hline & (1) & (2) & (3) & (4) & (5) & (6) \\
\hline & $\begin{array}{c}\text { Event } \\
\text { Window } \\
0 \\
\end{array}$ & $\begin{array}{c}\text { Event } \\
\text { Window } \\
(0,+1)\end{array}$ & $\begin{array}{c}\text { Event } \\
\text { Window } \\
(0,+2)\end{array}$ & $\begin{array}{c}\text { Event } \\
\text { Window } \\
(-1,+1)\end{array}$ & $\begin{array}{c}\text { Event } \\
\text { Window } \\
(-2,+2)\end{array}$ & $\begin{array}{c}\text { Event } \\
\text { Window } \\
(-2,+2)\end{array}$ \\
\hline AR & $\begin{array}{c}-1.391^{*} \\
(-1.76)\end{array}$ & $\begin{array}{c}-1.183^{* *} \\
(-2.11)\end{array}$ & $\begin{array}{c}-1.476 * * * \\
(-3.12)\end{array}$ & $\begin{array}{c}-0.957 * * \\
(-2.11)\end{array}$ & $\begin{array}{c}-1.180 * * * \\
(-3.23)\end{array}$ & $\begin{array}{c}-1.182 * * * \\
(-3.26)\end{array}$ \\
\hline AR $(-3,-7)$ & & & & & & $\begin{array}{l}-0.552 \\
(-1.57)\end{array}$ \\
\hline $\mathrm{AR}(+3,+7)$ & & & & & & $\begin{array}{l}0.136 \\
(0.39) \\
\end{array}$ \\
\hline CAR & $\begin{array}{c}-1.391 * \\
(-1.76) \\
\end{array}$ & \begin{tabular}{|c|}
$-2.366 * * *$ \\
$(-2.98)$ \\
\end{tabular} & \begin{tabular}{|c|}
$-4.428 * * *$ \\
$(-5.40)$ \\
\end{tabular} & \begin{tabular}{|c|}
$-2.871 * * *$ \\
$(-3.66)$ \\
\end{tabular} & $\begin{array}{c}-5.9 * * * \\
(-7.22) \\
\end{array}$ & $\begin{array}{c}-5.91 * * * \\
(-7.29) \\
\end{array}$ \\
\hline \multicolumn{7}{|c|}{ Panel C: IPO Firms $(N=54)$} \\
\hline & (1) & (2) & (3) & (4) & (5) & (6) \\
\hline & $\begin{array}{c}\text { Event } \\
\text { Window } \\
0\end{array}$ & $\begin{array}{c}\text { Event } \\
\text { Window } \\
(0,+1)\end{array}$ & $\begin{array}{c}\text { Event } \\
\text { Window } \\
(0,+2)\end{array}$ & $\begin{array}{l}\text { Event } \\
\text { Window } \\
(-1,+1)\end{array}$ & $\begin{array}{c}\text { Event } \\
\text { Window } \\
(-2,+2)\end{array}$ & $\begin{array}{c}\text { Event } \\
\text { Window } \\
(-2,+2)\end{array}$ \\
\hline AR & $\begin{array}{c}-2.661 * * * \\
(-3.05)\end{array}$ & $\begin{array}{c}-1.950 * * * \\
(-3.14)\end{array}$ & $\begin{array}{c}-1.938 * * * \\
(-3.71)\end{array}$ & $\begin{array}{c}-1.590 * * * \\
(-3.15)\end{array}$ & $\begin{array}{c}-1.631 * * * \\
(-4.05)\end{array}$ & $\begin{array}{c}-1.580 * * * \\
(-4.03)\end{array}$ \\
\hline $\operatorname{AR}(-3,-7)$ & & & & & & $\begin{array}{l}-0.421 \\
(-1.10)\end{array}$ \\
\hline $\mathrm{AR}(+3,+7)$ & & & & & & $\begin{array}{l}0.199 \\
(0.52)\end{array}$ \\
\hline CAR & $\begin{array}{c}-2.661 * * * \\
(-3.05)\end{array}$ & $\begin{array}{c}-3.9 * * * \\
(-4.44)\end{array}$ & \begin{tabular}{|c}
$-5.814 * * *$ \\
$(-6.43)$
\end{tabular} & $\begin{array}{c}-4.77 * * * \\
(-5.46) \\
\end{array}$ & $\begin{array}{c}-8.155 * * * \\
(-9.06) \\
\end{array}$ & $\begin{array}{c}-7.9 * * * \\
(-9.01)\end{array}$ \\
\hline
\end{tabular}




\begin{tabular}{|l|c|c|c|c|c|c|}
\hline \hline \multicolumn{2}{|c|}{ Panel D: Excluding Firms with Dual-Class Stock post IPO $(\mathbf{N}=\mathbf{4 1})$} \\
\hline \hline & $\mathbf{( 1 )}$ & $\mathbf{( 2 )}$ & $\mathbf{( 3 )}$ & $\mathbf{( 4 )}$ & $\mathbf{( 5 )}$ & $\mathbf{( 6 )}$ \\
\hline & Event & Event & Event & Event & Event & Event \\
& Window & Window & Window & Window & Window & Window \\
& 0 & $(0,+1)$ & $(0,+2)$ & $(-1,+1)$ & $(-2,+2)$ & $(-2,+2)$ \\
\hline AR & $-2.999 * * *$ & $-2.262 * * *$ & $-2.004 * * *$ & $-2.015 * * *$ & $-1.687 * * *$ & $-1.592 * * *$ \\
& $(-3.36)$ & $(-3.55)$ & $(-3.73)$ & $(-3.90)$ & $(-4.07)$ & $(-3.93)$ \\
AR $(-3,-7)$ & & & & & & -0.266 \\
& & & & & & $(-0.68)$ \\
AR $(+3,+7)$ & & & & & & 0.0395 \\
& & & & & & $(0.10)$ \\
\hline \hline CAR & $-2.999 * * *$ & $-4.524 * * *$ & $-6.012 * * *$ & $-6.045 * * *$ & $-8.435 * * *$ & $-7.96 * * *$ \\
& $(-3.36)$ & $(-5.020)$ & $(-6.461)$ & $(-6.755)$ & $(-9.101)$ & $(-8.788)$ \\
\hline
\end{tabular}

Panel E: Firms that Under-priced their Securities at the IPO $(\mathbf{N}=46)$

\begin{tabular}{|c|c|c|c|c|c|c|}
\hline & (1) & (2) & (3) & (4) & (5) & (6) \\
\hline & $\begin{array}{c}\text { Event } \\
\text { Window } \\
0\end{array}$ & $\begin{array}{c}\text { Event } \\
\text { Window } \\
(0,+1)\end{array}$ & $\begin{array}{c}\text { Event } \\
\text { Window } \\
(0,+2)\end{array}$ & $\begin{array}{c}\text { Event } \\
\text { Window } \\
(-1,+1)\end{array}$ & $\begin{array}{c}\text { Event } \\
\text { Window } \\
(-2,+2)\end{array}$ & $\begin{array}{c}\text { Event } \\
\text { Window } \\
(-2,+2)\end{array}$ \\
\hline $\mathrm{AR}$ & $\begin{array}{c}-1.556^{*} \\
(-1.69)\end{array}$ & $\begin{array}{c}-1.423 * * \\
(-2.18)\end{array}$ & $\begin{array}{c}-1.725 * * * \\
(-3.12)\end{array}$ & $\begin{array}{c}-1.185^{* *} \\
(-2.24)\end{array}$ & $\begin{array}{c}-1.463 * * * \\
(-3.44)\end{array}$ & $\begin{array}{c}-1.366 * * * \\
(-3.25)\end{array}$ \\
\hline $\operatorname{AR}(-3,-7)$ & & & & & & $\begin{array}{l}-0.527 \\
(-1.29)\end{array}$ \\
\hline $\mathrm{AR}(+3,+7)$ & & & & & & $\begin{array}{l}0.339 \\
(0.83)\end{array}$ \\
\hline CAR & $\begin{array}{c}-1.556^{*} \\
(-1.69)\end{array}$ & $\begin{array}{c}-2.846 * * * \\
(-3.083)\end{array}$ & $\begin{array}{c}-5.175 * * * \\
(-5.404)\end{array}$ & $\begin{array}{c}-3.555^{* * *} * \\
(-3.880)\end{array}$ & $\begin{array}{c}-7.315 * * * \\
(-7.692)\end{array}$ & $\begin{array}{c}-6.830 * * * \\
(-7.267)\end{array}$ \\
\hline
\end{tabular}

Panel F: Firms with a Share Price Higher than the IPO Price before Sciabacucchi $(\mathbf{N}=28)$

\begin{tabular}{|c|c|c|c|c|c|c|}
\hline & (1) & (2) & (3) & (4) & (5) & (6) \\
\hline & $\begin{array}{c}\text { Event } \\
\text { Window } \\
0\end{array}$ & $\begin{array}{c}\text { Event } \\
\text { Window } \\
(0,+1)\end{array}$ & $\begin{array}{c}\text { Event } \\
\text { Window } \\
(0,+2)\end{array}$ & $\begin{array}{c}\text { Event } \\
\text { Window } \\
(-1,+1)\end{array}$ & $\begin{array}{c}\text { Event } \\
\text { Window } \\
(-2,+2)\end{array}$ & $\begin{array}{c}\text { Event } \\
\text { Window } \\
(-2,+2)\end{array}$ \\
\hline AR & $\begin{array}{c}-2.381 * * \\
(-2.12)\end{array}$ & $\begin{array}{c}-1.449 * \\
(-1.81)\end{array}$ & $\begin{array}{c}-1.713 * * \\
(-2.54)\end{array}$ & $\begin{array}{l}-0.983 \\
(-1.51)\end{array}$ & $\begin{array}{c}-1.722 * * * \\
(-3.26)\end{array}$ & $\begin{array}{c}-1.723 * * * \\
(-3.33)\end{array}$ \\
\hline $\operatorname{AR}(-3,-7)$ & & & & & & $\begin{array}{l}-0.328 \\
(-0.65)\end{array}$ \\
\hline $\mathrm{AR}(+3,+7)$ & & & & & & $\begin{array}{l}0.177 \\
(0.35) \\
\end{array}$ \\
\hline CAR & $\begin{array}{c}-2.381 * * \\
(-2.12)\end{array}$ & $\begin{array}{c}-2.898 * * \\
(-2.560)\end{array}$ & $\begin{array}{c}-5.139 * * * \\
(-4.399)\end{array}$ & $\begin{array}{c}-2.949 * * * \\
(-2.615)\end{array}$ & $\begin{array}{c}-8.61 * * * \\
(-7.290)\end{array}$ & $\begin{array}{c}-8.615 * * * \\
(-7.446)\end{array}$ \\
\hline Observations & 121 & 122 & 123 & 123 & 125 & 135 \\
\hline
\end{tabular}


Appendix C: Variable Descriptions

\begin{tabular}{|c|c|c|}
\hline Variable & Description & Source \\
\hline Age & Firm age & $\begin{array}{l}\text { Jay Ritter } \\
\text { website }\end{array}$ \\
\hline \begin{tabular}{|l|} 
Delaware \\
Incorporated
\end{tabular} & $\begin{array}{l}\text { An indicator equal to } 1 \text { if the firm is } \\
\text { incorporated in Delaware }\end{array}$ & $\begin{array}{l}\text { Compustat, } \\
\text { Manual } \\
\text { checks }\end{array}$ \\
\hline $\begin{array}{l}\text { California } \\
\text { Hdq. }\end{array}$ & $\begin{array}{l}\text { An indicator equal to } 1 \text { if the firm is } \\
\text { headquartered in California }\end{array}$ & $\begin{array}{l}\text { Compustat, } \\
\text { Manual } \\
\text { checks }\end{array}$ \\
\hline $\begin{array}{l}\text { Vulnerable } \\
\text { Industry }\end{array}$ & $\begin{array}{l}\text { An indicator equal to } 1 \text { if a firm's Standard } \\
\text { Industrial Classification (SIC) code is } \\
\text { between 2833-2836 (Biotechnology), 3570- } \\
3577 \text { (Computer Hardware), 3600-3674 } \\
\text { (Electronics), 5200-5961 (Retail), and 7370- } \\
7374 \text { (Computer Software) }\end{array}$ & Compustat \\
\hline IPO Proceeds & $\begin{array}{l}\text { The proceeds of the IPO exclusive of } \\
\text { overallotment options }\end{array}$ & SDC \\
\hline \begin{tabular}{|l|} 
IPO Under- \\
pricing
\end{tabular} & $\begin{array}{l}\text { (Closing price on the first trading day of } \\
\text { IPO- } \text { offer price) / offer price. }\end{array}$ & SDC, CRSP \\
\hline $\begin{array}{l}\text { Dual-Class } \\
\text { Stock }\end{array}$ & $\begin{array}{l}\text { An indicator equal to } 1 \text { if the firm if } \\
\text { following the IPO the firm is a dual class } \\
\text { stock firm }\end{array}$ & $\begin{array}{l}\text { SEC Edgar } \\
\text { (manual } \\
\text { checks) }\end{array}$ \\
\hline $\begin{array}{l}\mathrm{VC} / \mathrm{PE} \\
\text { Backed IPO }\end{array}$ & $\begin{array}{l}\text { An indicator equal to } 1 \text { if the IPO is backed } \\
\text { by a venture capital investor or a private } \\
\text { equity firm }\end{array}$ & SDC \\
\hline $\begin{array}{l}\text { Negative } \\
\text { Earning }\end{array}$ & $\begin{array}{l}\text { An indicator equal to } 1 \text { if the firms' EBITDA } \\
\text { or Net Income is smaller than zero. EBITDA } \\
\text { is the the sum of sales minus cost of goods } \\
\text { sold minus selling, general and } \\
\text { administrative expenses. Net income is the } \\
\text { fiscal year income or loss reported by a } \\
\text { company after subtracting expenses and } \\
\text { losses from all revenues and gains. }\end{array}$ & Compustat \\
\hline Cash Ratio & $\begin{array}{l}\text { The firm's level of cash in } \$ \text { millions at the } \\
\text { end of the fiscal year divided by book value } \\
\text { of assets. }\end{array}$ & Compustat \\
\hline
\end{tabular}




\begin{tabular}{|l|l|l|}
\hline Variable & Description & Source \\
\hline Pre-Cyan & $\begin{array}{l}\text { An indicator equal to 1 if the IPO took place } \\
\text { during the period starting January 1, 2017 } \\
\text { and ending March 20, 2018 (when Cyan was } \\
\text { decided). }\end{array}$ & SDC \\
\hline $\begin{array}{l}\text { Post-Cyan } \\
\text { Pre- } \\
\text { Sciabacucchi }\end{array}$ & $\begin{array}{l}\text { An indicator equal to 1 if the IPO took place } \\
\text { during the period starting March 20, 2018 } \\
\text { (when Cyan was decided) and ending on } \\
\text { December 19, 2018 (when Sciabacucchi was } \\
\text { decided). }\end{array}$ & SDC \\
\hline $\begin{array}{l}\text { Post- } \\
\text { Sciabacucchi }\end{array}$ & $\begin{array}{l}\text { An indicator equal to 1 if the IPO took place } \\
\text { after December 19, 2018 (when } \\
\text { Sciabacucchi was decided). }\end{array}$ & SDC \\
\hline Law Firm & $\begin{array}{l}\text { An indicator equal to 1 if the firm retained } \\
\text { one of three law firms: Cooley, Godwin } \\
\text { Procter and Wilson Sonsini. }\end{array}$ & $\begin{array}{l}\text { SEC Edgar } \\
\text { (manual } \\
\text { checks) }\end{array}$ \\
\hline
\end{tabular}

